\title{
Measurement report: Effects of photochemical aging on the formation and evolution of summertime secondary aerosol in Beijing
}

\author{
Tianzeng Chen ${ }^{1}$, Jun Liu ${ }^{1,3}$, Qingxin Ma ${ }^{1,2,3}$, Biwu Chu ${ }^{1,2,3}$, Peng Zhang ${ }^{1}$, Jinzhu Ma ${ }^{1,2,3}$, Yongchun Liu ${ }^{4}$, \\ Cheng Zhong ${ }^{1,3}$, Pengfei Liu ${ }^{1}$, Yafei Wang ${ }^{5}$, Yujing $\mathbf{M u}^{1,2,3}$, and Hong $\mathrm{He}^{1,2,3}$ \\ ${ }^{1}$ State Key Joint Laboratory of Environment Simulation and Pollution Control, Research Center for Eco-Environmental \\ Sciences, Chinese Academy of Sciences, Beijing 100085, China \\ ${ }^{2}$ Center for Excellence in Regional Atmospheric Environment, Institute of Urban Environment, Chinese Academy of \\ Sciences, Xiamen 361021, China \\ ${ }^{3}$ University of Chinese Academy of Sciences, Beijing 100049, China \\ ${ }^{4}$ Beijing Advanced Innovation Center for Soft Matter Science and Engineering, Beijing University of Chemical Technology, \\ Beijing 100029, China \\ ${ }^{5}$ Beijing Institute of Petrochemical Technology, Beijing 102617, China
}

Correspondence: Qingxin Ma (qxma@rcees.ac.cn)

Received: 29 July 2020 - Discussion started: 25 August 2020

Revised: 30 November 2020 - Accepted: 23 December 2020 - Published: 1 February 2021

\begin{abstract}
Atmospheric submicrometer aerosols have a great effect on air quality and human health, while their formation and evolution processes are still not fully understood. Herein, the crucial role of atmospheric oxidation capacity, as characterized by $\mathrm{OH}$ exposure dose in the formation and evolution of secondary submicrometer aerosols, was systematically investigated based on a highly time-resolved chemical characterization of $\mathrm{PM}_{1}$ in a southern suburb of Beijing in summertime from 25 July to 21 August 2019. The averaged concentration of $\mathrm{PM}_{1}$ was $19.3 \pm 11.3 \mu \mathrm{g} \mathrm{m}^{-3}$, and nearly half $(48.3 \%)$ of the mass was organic aerosols (OAs) during the observation period. The equivalent photochemical age $\left(t_{\mathrm{a}}\right)$ estimated from the ratios of toluene to benzene was applied to characterize the $\mathrm{OH}$ exposure dose of the air mass, in which an observation period with the similar sources and minimal influence of fresh emission was adopted. The relationships of non-refractory $\mathrm{PM}_{1}$ species, $\mathrm{OA}$ factors (i.e., one hydrocarbon-like and three oxygenated organic aerosol factors) and elemental compositions (e.g., $\mathrm{H} / \mathrm{C}, \mathrm{O} / \mathrm{C}, \mathrm{N} / \mathrm{C}$, $\mathrm{S} / \mathrm{C}, \mathrm{OM} / \mathrm{OC}$, and OSc) to $t_{\mathrm{a}}$ were analyzed in detail. It was found that higher $\mathrm{PM}_{1}$ concentration accompanied longer $t_{\mathrm{a}}$, with an average increase rate of $0.8 \mu \mathrm{g} \mathrm{m}^{-3} \mathrm{~h}^{-1}$. Meanwhile, the formation of sulfate and more oxidized oxygenated OA were most sensitive to the increase in $t_{\mathrm{a}}$, and their contributions to $\mathrm{PM}_{1}$ were enhanced from $22 \%$ to $28 \%$ and from
\end{abstract}

$29 \%$ to $48 \%$, respectively, as $t_{\mathrm{a}}$ increased. In addition, OSc and the ratios of $\mathrm{O} / \mathrm{C}$ and $\mathrm{OM} / \mathrm{OC}$ increased with the increase in $t_{\mathrm{a}}$. These results indicated that photochemical aging is a key factor leading to the evolution of OA and the increase in $\mathrm{PM}_{1}$ in summertime.

\section{Introduction}

Fine particulate matter $\left(\mathrm{PM}_{2.5}\right)$ is one of the major atmospheric environmental problems, owing to its effects on air quality, human health, and climate (IPCC, 2013; Davidson et al., 2005; Molina and Molina, 2004). In recent years, the $\mathrm{PM}_{2.5}$ concentration in China exhibited a significant decrease with the implementation of the measures and strict policies in the Air Pollution Prevention and Control Action Plan (Zhang et al., 2019). However, the nationwide annual average concentration of $\mathrm{PM}_{2.5}$ is still greater than the standard of the World Health Organization (WHO) and $\mathrm{PM}_{2.5}$ is the primary pollutant in many regions, especially in the North China Plain (NCP). Beijing, one of the most polluted megacities in the NCP, is also facing severe $\mathrm{PM}_{2.5}$ pollution. The annual mean concentration in Beijing was $51 \mu \mathrm{g} \mathrm{m}^{-3}$ in 2018 (http://sthjj.beijing.gov.cn/, last access: 27 May 2020), which significantly exceeds the Chinese National Ambient 
Air Quality Standard (annual average of $35 \mu \mathrm{g} \mathrm{m}^{-3}$ ) and the WHO Standard (annual average of $10 \mu \mathrm{g} \mathrm{m}^{-3}$ ). Continuing to reduce the $\mathrm{PM}_{2.5}$ concentration is an important issue in improving the air quality in Beijing.

It has been well recognized that secondary aerosols (SAs), including secondary inorganic aerosol (SIA) and secondary organic aerosol (SOA), are the crucial constituents (30\%$77 \%$ ) of $\mathrm{PM}_{2.5}$ (Xie et al., 2020; An et al., 2019; Sun et al., 2016a; Guo et al., 2014; Huang et al., 2014). However, the formation and evolution mechanism of SA is still not well understood, mainly due to multiple precursors, complex formation processes, and meteorological conditions (Chen et al., 2020, 2019a; Duan et al., 2020, 2019; Hua et al., 2018; Li et al., 2018a; Tie et al., 2017; Sun et al., 2015). Therefore, from the perspective of precise $\mathrm{PM}_{2.5}$ control, in-depth understanding of the processes related to SA formation and evolution is crucial.

The Aerodyne high-resolution time-of-flight aerosol mass spectrometer (HR-ToF-AMS) has the advantage of real-time measurement of non-refractory submicrometer aerosol (NR$\mathrm{PM}_{1}$ ) with high time resolution and sensitivity compared to filter measurements (DeCarlo et al., 2006). As a result, HRToF-AMS measurements have been widely employed for illustrating the formation and evolution of PM in China (Chen et al., 2020; Xu et al., 2019b, 2014; Wu et al., 2018; Ge et al., 2017; Ye et al., 2017; Qin et al., 2016; Sun et al., 2016a; Huang et al., 2015; Li et al., 2015, 2013). Many previous field observation studies have inspected the formation mechanism and process of SA (Huang et al., 2019; Shi et al., 2019; Sun et al., 2018a, b, 2016b, 2014; Y. C. Wang et al., 2017, 2016; Xu et al., 2017; Cheng et al., 2016). For example, studies showed that an aqueous-phase process could be an important pathway in the formation of sulfate (Elser et al., 2016) and nitrate (Duan et al., 2020). However, most recent studies suggested that sulfate formation was also associated with a photochemical process, which is closely related to the meteorological conditions, especially in summertime (Chen et al., 2020; Duan et al., 2019). In terms of SOA, its contribution to $\mathrm{PM}_{2.5}$ was reported to be as important as SIA during haze events in China (Huang et al., 2014). However, the formation mechanism of SOA is much less understood compared to SIA because SOA consists of various organic species with different oxidation degrees. Meanwhile, based on the organics database measured by HR-ToF-AMS, positive matrix factorization (PMF) analysis, one receptor model (Paatero and Tapper, 1994), has been employed to distinguish and quantify multiple OA factors (Hu et al., 2016; Sun et al., 2016b). Studies have found that photochemical and aqueous-phase processes played different roles in the evolution of SOA, which depended on the level of atmospheric oxidation capacity (e.g., total oxidant $\left.\mathrm{O}_{x}\left(=\mathrm{O}_{3}+\mathrm{NO}_{2}\right)\right)$, relative humidity (RH), seasons, and regions (Chen et al., 2020; Feng et al., 2019; Y. C. Wang et al., 2017; Xu et al., 2017). For example, an aqueous-phase process was reported to have a significant effect on the formation of less oxidized oxy- genated OA (LO-OOA) and more oxidized oxygenated OA (MO-OOA) at low levels of atmospheric oxidation capacity in wintertime Baoji, Shaanxi (Y. C. Wang et al., 2017). However, $\mathrm{Xu}$ et al. (2017) demonstrated that the formation of MO-OOA was significantly dominated by the aqueousphase process, while LO-OOA was closely correlated with the photochemical process in urban Beijing (Xu et al., 2017). These inconsistences highlight the necessity of studying the role of atmospheric chemical processes in the formation and evolution of different types of SOA.

Previous studies have revealed some important factors (e.g., seasonal variation, meteorological factors, and pollution degree) that influence the formation and evolution of $\mathrm{PM}_{1}$ in Beijing based on AMS observations (Hu et al., 2016; Sun et al., 2013a, b, 2012; Zhang et al., 2014, respectively). Nevertheless, it should be pointed out that as the $\mathrm{PM}_{2.5}$ concentration decreases, the ozone $\left(\mathrm{O}_{3}\right)$ concentration increases year by year ( $\mathrm{Li}$ et al., 2019b; Zhang et al., 2019). $\mathrm{O}_{3}$ has become the primary air pollutant in summertime in the NCP and has caused the enhancement of atmospheric oxidation capacity. Therefore, there is an urgent need to investigate the impact of these changes on the atmospheric oxidation capacity and the formation and evolution of $\mathrm{PM}_{1}$. Moreover, it should be noted that most previous AMS observations in Beijing were carried out in urban areas (Duan et al., 2020; Xu et al., 2019b, 2017; Q. Wang et al., 2018; Li et al., 2017; Hu et al., 2016; Zhang et al., 2014; Sun et al., 2013a, b, 2012, 2010; Liu et al., 2012; Huang et al., 2010), while few studies were deployed in suburban areas (Chen et al., 2020; Li et al., 2019a). Considering the different meteorological factors and emission sources, the contribution of different formation and evolution pathways to $\mathrm{PM}_{1}$ in urban and suburban areas could be different.

In this study, a field observation, mainly using HR-ToFAMS, was conducted from 25 July to 21 August 2019 in a typical suburban site in Daxing District, which is the south gate of Beijing. The observation site lies in the air pollution transport channel between Beijing and Hebei province. Based on the measurement results of a series of gas- and particle-phase monitoring instruments, the chemical composition of NR-PM $M_{1}$, elemental ratios, and source categories of OA were analyzed. Moreover, the formation and evolution of secondary aerosols were elucidated. Specifically, the effects of atmospheric oxidation capacity, which was characterized using the equivalent photochemical age $\left(t_{\mathrm{a}}\right)$, on the formation of secondary aerosols were discussed.

\section{Experimental methods}

\subsection{Sampling site}

The online field observation was carried out in the top floor of a building (the ninth floor, $\sim 27 \mathrm{~m}$ above the ground) at the Qingyuan campus of Beijing Institute of Petrochem- 
ical Technology in Daxing District $\left(39.73^{\circ} \mathrm{N}, 116.33^{\circ} \mathrm{E}\right)$ from 25 July to 21 August 2019. The site is located between the 5th Ring Road and the 6th Ring Road in the south of Beijing and is a typical suburban site. Additionally, there is no additional source of pollution except for two adjacent streets (i.e., Xinghua Street and Qingyuan Street, with a distance $\sim 600 \mathrm{~m}$ ). The aerosols and gases were sampled using a $1 / 4 \mathrm{in}$. stainless steel tube and $1 / 4 \mathrm{in}$. PFA tube, respectively, and the sampling inlet extended out of the window about $2.0 \mathrm{~m}$ (Fig. S1 in the Supplement). For the aerosol sampling line, the total flow rate was adjusted to $6.0 \mathrm{~L} \mathrm{~min}^{-1}$ using an additional pump to reduce the residence time of aerosols $(\sim 0.7 \mathrm{~s})$. Meanwhile, an impactor with a size cut of $2.5 \mu \mathrm{m}$ was equipped in the front of this sampling inlet to remove coarse aerosols. A series of gas analyzers shared the gas sampling line, and the total flow rate was about $5.5 \mathrm{~L} \mathrm{~min}^{-1}$ with a corresponding residence time of gas of $\sim 0.8 \mathrm{~s}$. During the field observation period, the average temperature and $\mathrm{RH}$ were $28.3 \pm 3.3^{\circ} \mathrm{C}(22.1-$ $\left.37.7^{\circ} \mathrm{C}\right)$ and $62.0 \% \pm 17.5 \%(21.7 \%-93.6 \%)$, respectively. The wind speed was in a range of 0.40 to $5.37 \mathrm{~m} \mathrm{~s}^{-1}$ with an average value of $1.62 \pm 0.93 \mathrm{~m} \mathrm{~s}^{-1}$.

\subsection{Instrumentation}

The mass concentration and chemical composition of NR$\mathrm{PM}_{1}$ were simultaneously measured by a HR-ToF-AMS (Aerodyne Research Inc., USA). The detailed principles of HR-ToF-AMS can be found elsewhere (DeCarlo et al., 2006). Briefly, the aerosols are dried using a diffusion dryer containing silica gel before they enter the HR-ToF-AMS to minimize the impact of aerosol liquid water on collection efficiency (CE). Following this, the aerosols are sampled through a critical orifice and then concentrated into a narrow beam via an aerodynamic lens. The size of aerosol is determined using the flight time of particles to the thermal vaporization and ionization chamber. Then the aerosols are successively vaporized by a heated surface $\left(\sim 600^{\circ} \mathrm{C}\right)$, ionized by electron ionization $(\mathrm{EI}, 70 \mathrm{eV})$, and detected by a mass spectrometer detector. During this field observation, the HR-ToF-AMS was operated under alternation of two modes, i.e., 2 min $\mathrm{V}$ mode and $2 \mathrm{~min} \mathrm{~W}$ mode. The mass concentration of NR-PM 1 was derived from $\mathrm{V}$ mode considering its higher sensitivity, and the elemental ratios were obtained from $\mathrm{W}$ mode due to its higher resolution. Meanwhile, routine quality assurance and quality control procedures, mainly including the calibration of inlet flow, ionization efficiency (IE), and aerosol sizing, were carried out regularly every week according to the standard protocols, using pure dry mono-dispersed $300 \mathrm{~nm} \mathrm{NH}_{4} \mathrm{NO}_{3}$ aerosols (Chen et al., 2019b; Drewnick et al., 2005) to guarantee the credibility of the HR-ToF-AMS results. The size distribution and number concentration of aerosols with a mobility diameter from 13.6 to $736.5 \mathrm{~nm}$ were also measured by a custom-built scanning mobility particle sizer (SMPS, Model 3082 equipped with
3776 CPC, TSI, USA). PM $_{1}$ mass concentrations also calculated based on the volume concentration measured by SMPS and the estimated $\mathrm{PM}_{1}$ density (method details can be found in the Supplement). Its time series traced well with that from HR-ToF-AMS $\left(R^{2}=0.91\right.$; slope $=0.95 \pm 0.01$; see Fig. S2 in the Supplement).

The gas-phase species including $\mathrm{NO}_{x}, \mathrm{SO}_{2}, \mathrm{O}_{3}$, and $\mathrm{CO}$ were measured in real time by a series of Thermo analyzers (Model 42i-TL, 43i, 49i, 48i, respectively). The volatile organic compound (VOC) (e.g., benzene and toluene) concentrations were measured online using a vacuum ultraviolet single-photon ionization time-of-flight mass spectrometer (SPIMS-3000, Guangzhou Hexin Analytical Instrument Co., Ltd., China). These instruments were calibrated periodically with the corresponding standard gas to ensure the accuracy of the observation data. In addition, the meteorological parameters including temperature $(T), \mathrm{RH}$, and wind speed and direction were recorded by an automatic weather station (Vaisala M451).

\subsection{Data analysis}

\subsubsection{HR-ToF-AMS data analysis}

The standard analysis software tool (SQUIRREL, version 1.57I and PIKA, version 1.16I) written in Igor Pro (version 6.37, Wavemetrics Inc., USA) was used to analyze the HRToF-AMS data. In order to obtain the quantitative mass concentrations of different species (i.e., $\mathrm{OA}, \mathrm{SO}_{4}, \mathrm{NO}_{3}, \mathrm{NH}_{4}$, and $\mathrm{Cl}$ ), and considering that the aerosols were almost neutral and had been dried before entering into the HR-ToF-AMS inlet, the collection efficiency factor (CE) was determined according to the following equation (Middlebrook et al., 2012):

$\mathrm{CE}=\max (0.45,0.0833+0.9167 \cdot \mathrm{ANMF})$,

where ANMF is the mass fraction of $\mathrm{NH}_{4} \mathrm{NO}_{3}$ in NR-PM $\mathrm{P}_{1}$. The default relative ionization efficiency (RIE) values were used for OA (1.4), $\mathrm{NO}_{3}$ (1.1), and $\mathrm{Cl}$ (1.3) (Jimenez et al., 2003). As for $\mathrm{NH}_{4}$ and $\mathrm{SO}_{4}$, their RIE values were determined using the pure dry mono-dispersed $\mathrm{NH}_{4} \mathrm{NO}_{3}$ and $\left(\mathrm{NH}_{4}\right)_{2} \mathrm{SO}_{4}$ aerosols to be 4.0 and 1.2 , respectively.

Elemental analysis (EA) was also executed using the "Improved Ambient" method (Canagaratna et al., 2015) to obtain the hydrogen-to-carbon ratio $(\mathrm{H} / \mathrm{C})$, oxygen-to-carbon ratio $(\mathrm{O} / \mathrm{C})$, and organic-mass to organic-carbon ratio $(\mathrm{OM} / \mathrm{OC})$, as well as elemental ratios of $\mathrm{N} / \mathrm{C}$ and $\mathrm{S} / \mathrm{C}$. The average carbon oxidation state (OSc) can be approximated by $2 \cdot \mathrm{O} / \mathrm{C}-\mathrm{H} / \mathrm{C}$ and is a metric describing the oxidation degree of atmospheric OA (Kroll et al., 2011).

\subsubsection{PMF analysis of $\mathrm{OA}$}

Source apportionment of OA was executed using the PMF model to analyze the HR-ToF-AMS mass spectral data to identify the main organic components and their sources 
(Zhang et al., 2011). PMF, as a bilinear receptor model, can be expressed as the following equation (Paatero, 1997; Paatero and Tapper, 1994):

$\mathbf{X}=\mathbf{G F}+\mathbf{E}$,

where $\mathbf{X}$ is the observed data matrix with dimensions of $n \times$ $m$. $\mathbf{G}$ is the factor contribution matrix of dimensions $n \times p, \mathbf{F}$ is the factor profile matrix of dimensions $p \times m$, and $\mathbf{E}$ is the matrix of residuals with dimensions of $n \times m . n, m$, and $p$ are the number of samples, species, and factors, respectively.

A least-squares fitting method was used to minimize the object function $Q$, which is defined as the sum of the squared residuals $\left(e_{i j}\right)$ weighted by their degree of measurement uncertainty $\left(\sigma_{i j}\right)$.

$Q=\sum_{i=1}^{n} \sum_{j=1}^{m}\left(e_{i j} / \sigma_{i j}\right)^{2}$

In our study, the PMF software tool (PMF Evaluation Tool, PET, version 2.06) (Ulbrich et al., 2009) written in Igor Pro (version 6.37, Wavemetrics Inc., USA) was used to analyze the HR-ToF-AMS mass spectra $(m / z, 12-170)$. The detailed steps have been expressed in Zhang et al. (2011). According to the values of the signal-to-noise ratio (SNR), $m / z$ values with SNR in a range of 0.2-2 were weak variables and downweighted two times, and $m / z$ values with SNR less than 0.2 were bad variables and directly removed. As for duplicate information, $m / z, 44\left(\mathrm{CO}_{2}\right)$ and related $\mathrm{m} / z$ values (including $16(\mathrm{O}), 17(\mathrm{HO}), 18\left(\mathrm{H}_{2} \mathrm{O}\right)$, and $28(\mathrm{CO})$ ) were also down-weighted. Then PMF was run for a range of factors (from 1 to 5) and rotational parameters (FPEAK) (from -1 to 1 with a step of 0.2 ). After considering multiple criteria, including mass spectral features, diurnal patterns, correlation with external tracers, and temporal variations (Zhang et al., 2011), the best number of factors was determined to be 4 (detailed diagnostics are shown in Fig. S3 in the Supplement), including one hydrocarbon-like OA (HOA) factor and three oxygenated organic aerosol factors (LO-OOA, IOOOA and MO-OOA; IO-OOA is an abbreviation for intermediate oxidized oxygenated OA). The corresponding mass spectra, time series, and diurnal variation, which are similar to our previous results observed at the same site during summertime 2018 (Chen et al., 2020), are given in Fig. S4 in the Supplement.

\subsubsection{Photochemical age}

In the ambient air, the reaction of benzene and toluene with $\mathrm{O}_{3}$ and $\mathrm{NO}_{3}$ radicals is very slow, with reaction rates on the order of $<10^{-20}$ and $<10^{-16} \mathrm{~cm}^{3}$ molecule ${ }^{-1} \mathrm{~s}^{-1}$, respectively (Atkinson and Arey, 2003), which are significantly lower than the reaction rate with $\mathrm{OH}$ radicals $\left(10^{-12} \mathrm{~cm}^{3}\right.$ molecule $\left.{ }^{-1} \mathrm{~s}^{-1}\right)$. Thus, their degradation is dominated by reaction with $\mathrm{OH}$ radicals. Meanwhile, the reaction rate of toluene with $\mathrm{OH}$ radicals is about 5 times that of benzene. Therefore, their degradation rates in the ambient air are significantly different after being exhausted from an emission source, which would lead to an observable change in their concentration ratio. Consequently, the ratio of toluene to benzene is typically used to study the photochemical aging process of localized air masses (Yuan et al., 2012; Parrish et al., 2007; de Gouw et al., 2005; Gelencsér et al., 1997; McKeen et al., 1996).

In this study, the equivalent photochemical age $\left(t_{\mathrm{a}}\right)$ was calculated to characterize the $\mathrm{OH}$ exposure dose of the air mass, as expressed in the following equation. This method had been widely used to provide useful information on the photochemical process in the atmosphere (Yuan et al., 2012; Parrish et al., 2007; de Gouw et al., 2005; McKeen et al., 1996).

$$
\begin{aligned}
t_{\mathrm{a}}= & \frac{1}{[\mathrm{OH}]\left(k_{\text {toluene }}-k_{\text {benzene }}\right)} \\
& \cdot\left[\ln \left(\frac{[\text { toluene }]}{[\text { benzene }]}\right)_{0}-\ln \left(\frac{[\text { toluene }]}{[\text { benzene }]}\right)\right],
\end{aligned}
$$

where $[\mathrm{OH}]$ is the average $\mathrm{OH}$ concentration in the ambient air and is assumed as $1.5 \times 10^{6}$ molecule $\mathrm{cm}^{-3}$ according to previous studies (Mao et al., 2009; Chu et al., 2016; Liu et al., 2018). $k_{\text {toluene }}$ and $k_{\text {benzene }}$ are the rate constants for the reactions of $\mathrm{OH}$ with toluene $\left(5.63 \times 10^{-12} \mathrm{~cm}^{3}\right.$ molecule $\left.{ }^{-1} \mathrm{~s}^{-1}\right)$ and benzene $\left(1.22 \times 10^{-12} \mathrm{~cm}^{3}\right.$ molecule $\left.{ }^{-1} \mathrm{~s}^{-1}\right)$, respectively (Atkinson and Arey, 2003). ([toluene] $)_{0}$ is the emission concentration ratio of toluene and benzene before aging in the atmosphere and was determined to be $2.71 \pm 0.39$ (Fig. S6 in the Supplement) according to the methods described by de Gouw et al. (2017), where the ratio at nighttime was used to avoid the impact of photochemistry and boundary layer dilution on the emission ratio. [toluene] is the measured concentration ratio of toluene and benzene, as given in Fig. S6. Based on the back trajectories and air mass cluster analysis (Draxier and Hess, 1998) (Details can be found in the Supplement), an observation period (Cluster 2, Fig. S5 in the Supplement) with the similar emission sources was adopted. Furthermore, the data observed from 10:00 to 18:00 UTC +8 was used to minimize the influence of fresh emission during the morning and evening rush hours on $t_{\mathrm{a}}$, as discussed by Qin et al. (2016). In this study, $t_{\mathrm{a}}$ was determined to be in the range of $4-90 \mathrm{~h}$, which is comparable to previous studies (up to $72 \mathrm{~h}$ ) conducted in China (Peng et al., 2016; Chu et al., 2021). Meanwhile, $t_{\mathrm{a}}$ had a higher level at noon, which is similar to the diurnal trend of $\mathrm{OH}$ radicals observed in summertime of Beijing (Tan et al., 2019).

\section{Results and discussion}

\subsection{Chemical compositions of $\mathbf{P M}_{1}$}

The time series of mass concentrations of NR-PM $\mathrm{PM}_{1}$ species (i.e., $\mathrm{OA}, \mathrm{SO}_{4}, \mathrm{NO}_{3}, \mathrm{NH}_{4}$, and $\mathrm{Cl}$ ) and their relative contributions are summarized in Fig. 1. During this field observation, 


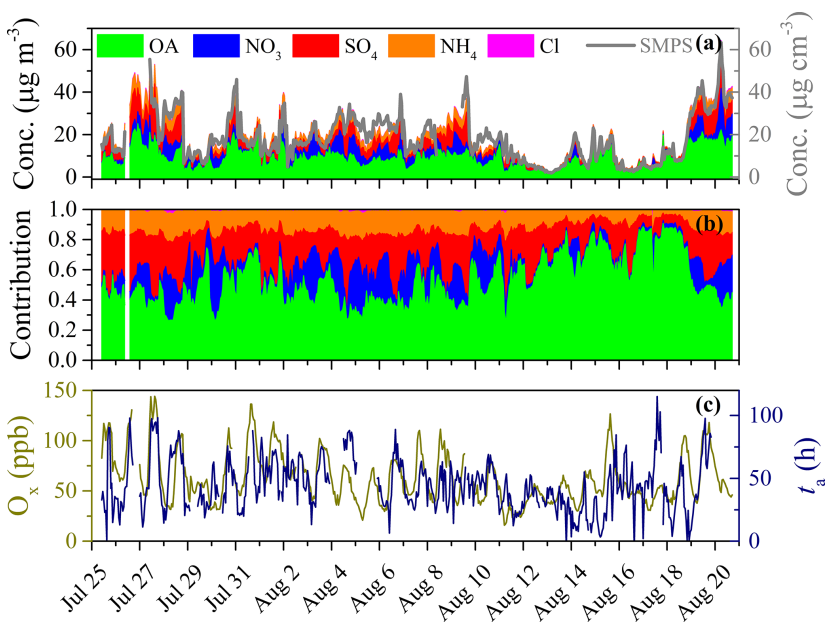

Figure 1. Overview of time series of (a) concentrations of NR-PM species derived from HR-ToF-AMS (left $y$ axis) and SMPS (right $y$ axis), (b) relative contributions of NR-PM 1 species, and (c) concentration of total oxidant $\left(\mathrm{O}_{x}=\mathrm{O}_{3}+\mathrm{NO}_{2}\right)$ and photochemical age $\left(t_{\mathrm{a}}\right)$ during this field observation.

the hourly mass concentrations of NR-PM $\mathrm{PM}_{1}$ were in the range of 2.2-64.3 $\mu \mathrm{g} \mathrm{m}^{-3}$, with an average of $19.3 \pm 11.3 \mu \mathrm{g} \mathrm{m}^{-3}$, which is close to those observed in a suburb of Beijing in summer $2016\left(14.2 \pm 9.4 \mu \mathrm{g} \mathrm{m}^{-3}\right.$, Li et al., 2019a) and summer $2018\left(24.1 \pm 18.0 \mu \mathrm{g} \mathrm{m}^{-3}\right.$, Chen et al., 2020). However, this averaged $\mathrm{PM}_{1}$ concentration was much lower than those observed in urban Beijing in summertime, such as $80 \pm 40.6 \mu \mathrm{g} \mathrm{m}^{-3}$ in 2006 (Sun et al., 2010), $63.1 \mu \mathrm{g} \mathrm{m}^{-3}$ in 2008 (Huang et al., 2010), $50 \pm 30 \mu \mathrm{g} \mathrm{m}^{-3}$ in 2011 (Sun et al., 2012), and $37.5 \pm 31.0 \mu \mathrm{g} \mathrm{m}^{-3}$ in 2012 (Hu et al., 2017). Meanwhile, among all species in NR-PM 1 , OA contributed the most $(48.3 \%)$, indicating the dominant role of $\mathrm{OA}$ in summertime $\mathrm{PM}_{1}$ pollution (Chen et al., 2020; $\mathrm{Hu}$ et al., 2016; Sun et al., 2015; Zhang et al., 2014). Moreover, the largest daily contribution of OA $(>80 \%)$ was observed during the clean period, with $\mathrm{PM}_{1}$ concentrations less than $20 \mu \mathrm{g} \mathrm{m}^{-3}$ (e.g., from 16 to 18 August 2019, Fig. 1b). On the other hand, SIA accounted for $51.7 \%$ of NR-PM in which sulfate was the largest contributor $(23.2 \%)$, followed by nitrate $(14.3 \%)$, ammonium (13.4\%), and chloride $(0.8 \%)$. Similar relative contributions of these species were also observed in a suburb of Beijing in summer 2016, where OA contributed a mass fraction of $42 \%-71 \%$, followed by sulfate $(15 \%-27 \%)$, nitrate $(6 \%-22 \%)$, ammonium ( $8 \%-$ $13 \%)$, and chloride $(0.3 \%-0.6 \%)$ (Li et al., 2019a). The percentage of different chemical species in $\mathrm{PM}_{1}$ reported in previous observations in summertime of Beijing in urban and suburban was compared in Fig. S7 in the Supplement. Typically, the fraction of OA (48.3\%) in suburban Beijing is higher than those in urban Beijing (33\%-38\%), while the contribution of SIA $(51.7 \%)$ in suburban Beijing is smaller than those in urban Beijing (58\%-64\%) (Hu et al., 2017;
Huang et al., 2010; Sun et al., 2010, 2012). The reason may be the difference in the emissions of gaseous precursors (e.g., $\mathrm{SO}_{2}$ and $\mathrm{NO}_{x}$ ) and their conversion ratio to SIA (Hu et al., 2017; Li et al., 2020). Meanwhile, the inorganic sulfate, nitrate, and chloride could be well neutralized by ammonium during this field observation since there is an extremely good linear relationship between $\mathrm{NO}_{3}+2 \cdot \mathrm{SO}_{4}+\mathrm{Cl}$ and $\mathrm{NH}_{4}$ $\left(R^{2}=0.998\right.$, slope $=0.992 \pm 0.002$, Fig. S8 in the Supplement). This implied the significant contribution of gaseous $\mathrm{NH}_{3}$ to the formation of SIA and $\mathrm{PM}_{2.5}$. Therefore, $\mathrm{NH}_{3}$ emission control in China should be strengthened in the future to mitigate PM pollution (Liu et al., 2019b).

Figure 1 also presents the time series of total oxidant $\left(\mathrm{O}_{x}=\mathrm{O}_{3}+\mathrm{NO}_{2}\right)$ and photochemical age $\left(t_{\mathrm{a}}\right)$. In this study, $t_{\mathrm{a}}$ and $\mathrm{O}_{x}$ can be used to characterize the photochemical aging process undergone and the total oxidant present in the ambient atmosphere, respectively. As shown in Fig. 1c, $t_{\mathrm{a}}$ showed a similar evolutionary trend to that of $\mathrm{O}_{x}$, with a high correlation coefficient $\left(R^{2}=0.75\right)$ during this summertime observation, implying there may exist a correlation between $\mathrm{O}_{x}$ and $t_{\mathrm{a}}$. It is well known that the photochemical aging process of VOCs can form organic peroxy radical $\left(\mathrm{RO}_{2}\right)$ and then accelerate the cycle of $\mathrm{NO}_{x}$ and the formation of $\mathrm{O}_{3}$ in the atmosphere. Therefore, a longer aging time $\left(t_{\mathrm{a}}\right)$ implies that more VOCs are consumed and more $\mathrm{RO}_{2}$ is formed. Consequently, the transform cycles of $\mathrm{NO}_{x}$ and the accumulation of $\mathrm{O}_{3}$ would be accelerated under these conditions ( $\mathrm{T}$. Wang et al., 2017).

\subsection{Role of photochemical aging in aerosol formation and composition}

In order to evaluate the effect of the photochemical aging process, the relationships between $\mathrm{O}_{x}, \mathrm{PM}_{1}$, OA concentration, and binned $t_{\mathrm{a}}$ were analyzed and shown in Fig. 2. These species concentrations all increase positively with the increasing of $t_{\mathrm{a}}$. Meanwhile, with the increase in $t_{\mathrm{a}}$, concentrations of $\mathrm{PM}_{1}$ and $\mathrm{O}_{3}$ increased simultaneously (Fig. 2 and $\mathrm{S} 9$ in the Supplement), suggesting that the photochemical aging process may have an important contribution to the formation of $\mathrm{PM}_{1}$ and $\mathrm{O}_{3}$ during summertime in Beijing. The possible reason is that high temperature in summer can volatilize more VOCs from biogenic sources (Fu et al., 2010) and anthropogenic sources (Pusede et al., 2014) (such as paint, as in McDonald et al., 2018, and asphalt, as in Khare et al., 2020), which could promote the formation of $\mathrm{O}_{3}$ and $\mathrm{PM}_{1}$ ( $\mathrm{Li}$ et al., 2019c; Schnell and Prather, 2017). This was also verified by the positive correlation between $t_{\mathrm{a}}$ and $T$ (Fig. S6). Further analysis showed that the concentration of $\mathrm{O}_{3}$ significantly decreased with increasing $\mathrm{NO}_{x}$ in this observation period (Fig. S9b), implying the VOC-sensitive regime of $\mathrm{O}_{3}$ formation. Thus, increased VOCs will produce more $\mathrm{RO}_{2}$ and $\mathrm{O}_{3}$ locally (Li et al., 2018b), as well as more OA, since SOA (predominant species in $\mathrm{OA}$ ) mainly originates from the pho- 


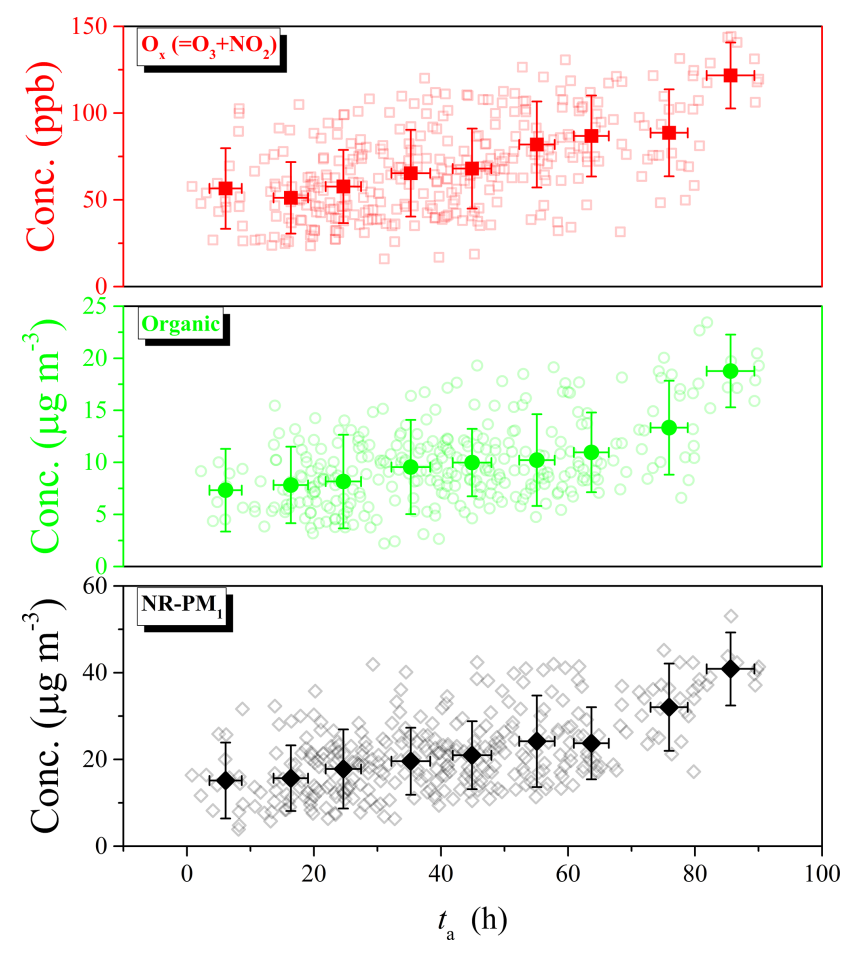

Figure 2. Relationship between photochemical age $\left(t_{\mathrm{a}}\right)$ and total oxidant $\left(\mathrm{O}_{x}\right), \mathrm{NR}-\mathrm{PM}_{1}$ concentration, and organic concentration during the observation period included by Cluster 2 . The data are binned according to the value of $t_{\mathrm{a}}(10 \mathrm{~h}$ increment $)$.

tochemical process of VOCs (Fan et al., 2020; Fu et al., 2014; Hallquist et al., 2009).

The time series of total OOA $(=\mathrm{LO}-\mathrm{OOA}+\mathrm{IO}-$ $\mathrm{OOA}+\mathrm{MO}-\mathrm{OOA}$ ) and $\mathrm{O}_{x}$ was also compared (Fig. 3) and they presented similar temporal changes $\left(R^{2}=0.85\right)$. As shown in the inset of Fig. 3, the regression slope for OOA vs. $\mathrm{O}_{x}$ was determined to be $0.130 \pm 0.002 \mu \mathrm{g} \mathrm{m}^{-3} \mathrm{ppb}^{-1}$, which was slightly lower than those observed in Pasadena, CA $\left(0.146 \pm 0.001 \mu \mathrm{g} \mathrm{m}^{-3} \mathrm{ppb}^{-1}\right)$ (Hayes et al., 2013); Riverside, CA $\left(0.142 \pm 0.004 \mathrm{\mu g} \mathrm{m}^{-3} \mathrm{ppb}^{-1}\right)$ (Docherty et al., 2011); and Mexico City $\left(0.156 \pm 0.001 \mu \mathrm{g} \mathrm{m}^{-3} \mathrm{ppb}^{-1}\right)$ (Aiken et al., 2009). This might be related to the observed high concentrations of light alkenes during this period. These species will cause high $\mathrm{O}_{3}$ concentrations but will not contribute greatly to the formation of SOA. The scatter data are colored by the time of day, and the slope observed in the morning is steeper than that in the afternoon, which was also observed in other field measurements and was mainly due to the increased evaporation of IO-OOA (Hayes et al., 2013; Herndon et al., 2008; Wood et al., 2010). These results implied that the formation and evolution of PM pollution and OA were closely related to the photochemical aging process and total oxidant present during the summertime, which need to be deeply explored to understand the growth of $\mathrm{PM}_{1}$.

To further investigate the role of $t_{\mathrm{a}}$ in aerosol formation, all NR-PM 1 species and OA factors were normalized to HOA to exclude the accumulation and/or dilution effects in the atmosphere, and the corresponding ratios as a function of $t_{\mathrm{a}}$ are given in Fig. 4. Although the HOA emissions vary throughout the day and might bring some uncertainty, Sun et al. (2013a) indicated that this uncertainty might be reduced and become insignificant when these databases are averaged (as a function of $t_{\mathrm{a}}$ in this study). The normalized ratios of

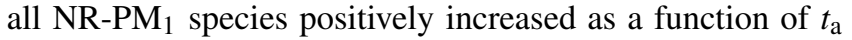
with different increase rates. At low $t_{\mathrm{a}}$ levels $(<40 \mathrm{~h})$, relatively small ratios of all species could be observed, and all ratios showed a slight increase trend. However, at $t_{\mathrm{a}}=70$ $80 \mathrm{~h}$, the normalized concentration of total NR-PM $\mathrm{PM}_{1}$, organic aerosol, and sulfate increased by a factor of $>6$ compared with that at low $t_{\mathrm{a}}$ levels $(<40 \mathrm{~h})$. This indicated that these species were susceptible to photochemical aging processes in the summer with strong solar radiation. Exponential fitting $(y=A \cdot \exp (x / B)+C)$ was applied to quantitatively describe the relationship between these species and $t_{\mathrm{a}}$, as given in Fig. 4. The fitting parameter $B$ could be used to characterize the sensitivity of each species to the increase in $t_{\mathrm{a}}$, while smaller $B$ means more sensitivity to $t_{\mathrm{a}}$. According to the fitting results, the formation of NR-PM 1 was most sensitive to $t_{\mathrm{a}}$, followed by sulfate and organic aerosol in sequence. Their average increase rates in absolute mass concentration (Fig. S10 in the Supplement) showed the same trend as the normalized ratios in Fig. 4. The average increase rate of sulfate was the largest $\left(0.4 \mu \mathrm{g} \mathrm{m}^{-3} \mathrm{~h}^{-1}\right)$ among NR-PM ${ }_{1}$ species, while that of NR-PM was $0.8 \mu \mathrm{g} \mathrm{m}^{-3} \mathrm{~h}^{-1}$. These results also suggested that the photochemical aging process plays an important role in sulfate formation in summertime (Li et al., 2020). Previous studies have revealed that an aqueous-phase process plays an important role in sulfate formation (Sun et al., 2015, 2013a). However, it appears that photochemical oxidation was the primary pathway of sulfate formation in the present summertime observation, as seen in the $t_{\mathrm{a}}$ - and RH-dependent distributions of sulfate (Fig. S11 in the Supplement). Both the sulfate mass concentration and its proportion in $\mathrm{PM}_{1}$ were highly dependent on $t_{\mathrm{a}}$ rather than $\mathrm{RH}$. As for nitrate, the corresponding ratio first increased and then slightly decreased as $t_{\mathrm{a}}$ increased, which was similar to the evolution trend of absolute mass concentration (Fig. S10). It is worth noting that the concentration of $\mathrm{NO}_{x}$ decreased with increasing $t_{\mathrm{a}}$ (Fig. S12 in the Supplement), suggesting the photochemical oxidation of $\mathrm{NO}_{x}$ to $\mathrm{HNO}_{3}$ or nitrate. This was in agreement with the observation of high concentrations of $\mathrm{NO}_{z}\left(\mathrm{NO}_{z}=\mathrm{NO}_{y}-\mathrm{NO}_{x}\right)$ at elevated $t_{\mathrm{a}}$ levels (Fig. S12). Meanwhile, high temperature accompanied high levels of $t_{\mathrm{a}}$ (Fig. S12), which could cause the evaporation of nitrate or adsorbed $\mathrm{HNO}_{3}$ into the gas phase (Xu et al., 2019a). As demonstrated by the $t_{\mathrm{a}}$ - and RH-dependent distributions of nitrate (Fig. S11), the aqueous-phase process made a significant contribution to the formation of nitrate (Duan et al., 2020).

Regarding the OA factors, they exhibited different dependence on $t_{\mathrm{a}}$, as presented in Fig. 4. Among these four OA fac- 


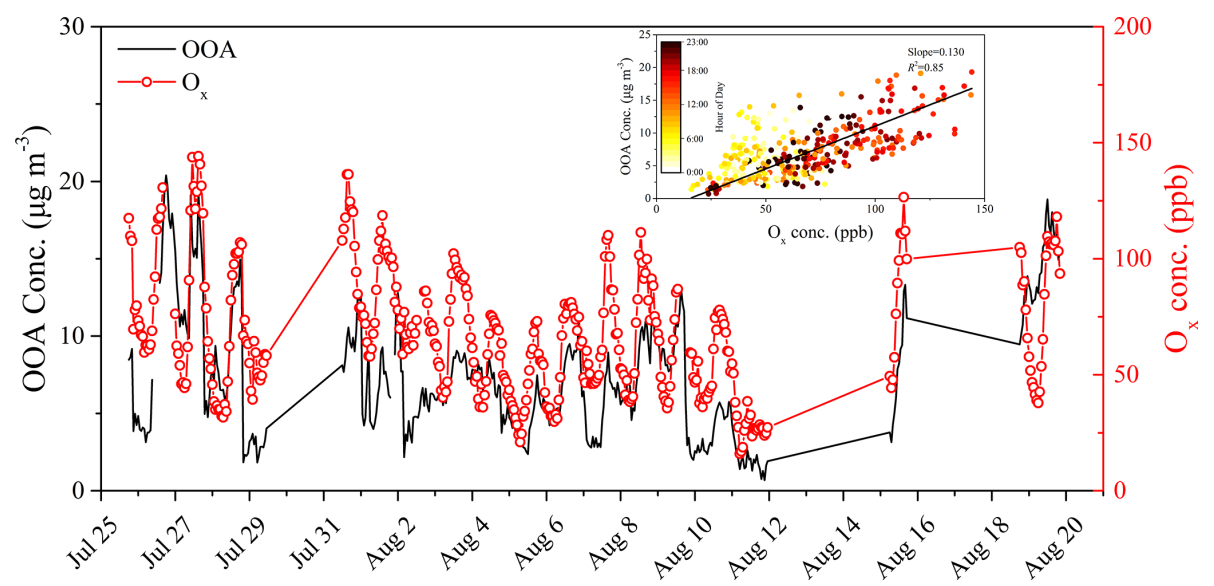

Figure 3. Time series of OOA ( $=\mathrm{LO}-\mathrm{OOA}+\mathrm{IO}-\mathrm{OOA}+\mathrm{MO}-\mathrm{OOA})$ and $\mathrm{O}_{x}\left(=\mathrm{O}_{3}+\mathrm{NO}_{2}\right)$. The inset is a scatterplot of OOA vs. $\mathrm{O}_{x}$ with linear fit and colored by the time of day. The regression slope is $0.130\left(R^{2}=0.85\right)$.
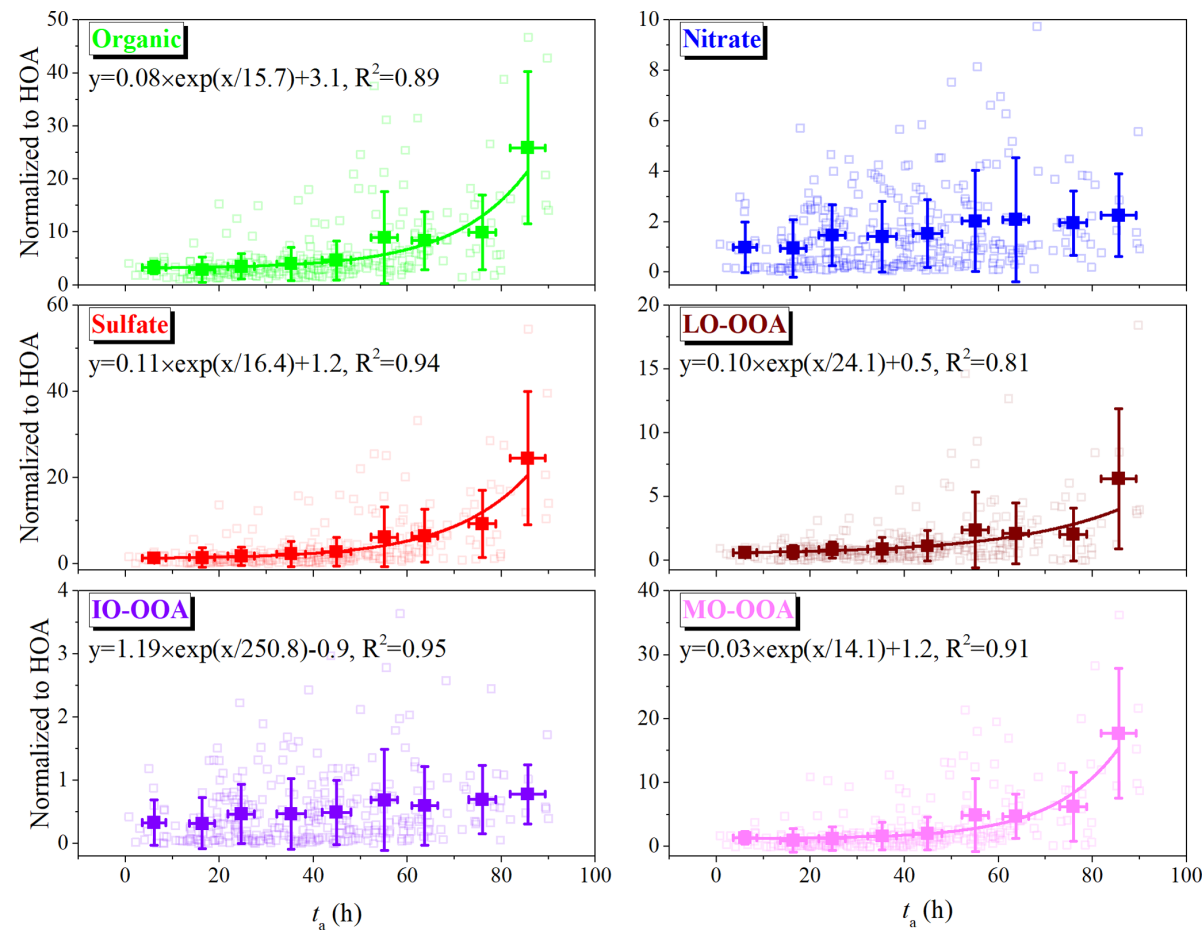

Figure 4. Variations of the ratios of mass concentrations of NR-PM 1 species and OA factors to HOA as a function of $t_{\mathrm{a}}$. The data are binned according to the value of $t_{\mathrm{a}}(10 \mathrm{~h}$ increments $)$. The solid lines are the results of exponential fitting with the function of $y=A \cdot \exp (x / B)+C$.

tors, MO-OOA was most affected by the increase in $t_{\mathrm{a}}$, with a factor of $\sim 13$ compared with that at low $t_{\mathrm{a}}$ levels $(<40 \mathrm{~h})$. The enhancement factor of LO-OOA with increased $t_{\mathrm{a}}$ was $\sim 10$, which might be due to its lower oxidation state $(\mathrm{OSc}=-0.34)$ than that of MO-OOA (OSc $=-0.23)$. These results are consistent with the exponential fitting parameter $B$ of MO-OOA and LO-OOA in Fig. 4. The average increase rate of MO-OOA $\left(0.3 \mu \mathrm{g} \mathrm{m}^{-3} \mathrm{~h}^{-1}\right)$ was also significantly larger than that of LO-OOA, with a factor of $\sim 7$. As for IO-OOA, $t_{\mathrm{a}}$ exhibited a slight enhancement effect, sug- gesting that photochemical aging may be not its main formation pathway. In contrast, the normalized concentration of IO-OOA and its contribution to $\mathrm{PM}_{1}$ significantly depended on RH (Fig. S13 in the Supplement), which was consistent with the results of Herrmann et al. (2015).

Additionally, the evolution of OA/ $\Delta \mathrm{CO}$ as a function of $t_{\mathrm{a}}$ was also presented in Fig. S14 in the Supplement, in which $\triangle \mathrm{CO}$ was obtained by the measured $\mathrm{CO}$ concentrations subtracting its background concentration, and the latter was determined to be $0.1 \mathrm{ppm}$ according to the method described by 
(a)

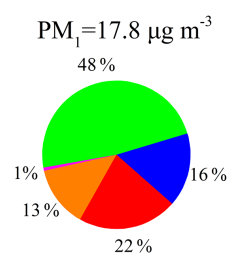

(b)

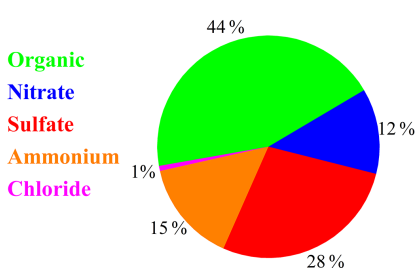

Figure 5. Different chemical compositions of NR-PM 1 and OA factor contributions during the (a) low $t_{\mathrm{a}}(<40 \mathrm{~h})$ period and (b) high $t_{\mathrm{a}}(>40 \mathrm{~h})$ period. The displayed $\mathrm{PM}_{1}, \mathrm{OA}$, and $t_{\mathrm{a}}$ are averages of values during the corresponding period.

DeCarlo et al. (2010). As shown in Fig. S14, the concentration ratio of organic aerosol and OOA (especially for MOOOA) to $\triangle \mathrm{CO}$ also increased significantly with $t_{\mathrm{a}}$, which could be attributed to the SOA formation from the photochemical process and is also similar to the evolution trend of the ratios of OA components to HOA with $t_{\mathrm{a}}$ (Fig. 4). These results further indicated the positive role of the photochemical aging process in aerosol formation.

Figure 5 shows the averaged contributions of NR-PM species and OA factors at low and high $t_{\mathrm{a}}$ levels. The average mass concentration of NR-PM 1 at $t_{\mathrm{a}}>40 \mathrm{~h}$ was $25.3 \mu \mathrm{g} \mathrm{m}^{-3}$, which was 1.4 times that at $t_{\mathrm{a}}<40 \mathrm{~h}$. All NR-PM $\mathrm{P}_{1}$ species were enhanced in mass concentration by a factor of more than 1.1 at elevated $t_{\mathrm{a}}$, of which sulfate had the largest enhancement factor of 1.7. OA was the dominant species in NR-PM 1 at both $t_{\mathrm{a}}$ levels, although its percentage decreased from $48 \%$ to $44 \%$ with the increase in $t_{\mathrm{a}}$. This decreased percentage could be attributed to the significantly decreased contribution of HOA (from $37 \%$ to $20 \%$ ) with the enhancement of $t_{\mathrm{a}}$, suggesting that the photochemical aging process was not conducive to the accumulation of HOA. Comparing the contribution of other species to NR-PM 1 at low and high $t_{\mathrm{a}}$ levels, it was found that the contribution of sulfate was enhanced from $22 \%$ to $28 \%$ as $t_{\mathrm{a}}$ increased, which confirmed that the formation of sulfate was closely related to the photochemical process. The contribution of nitrate presented a decreasing trend (from $16 \%$ to $12 \%$ ) as $t_{\mathrm{a}}$ increased, which could be due to the enhanced production of OOA and sulfate as $t_{\mathrm{a}}$ increased, as well as the dilution effects and evaporation of ammonium nitrate (DeCarlo et al., 2008; Nault et al., 2018).

The OA factors also presented different change trends and different compositions at high $t_{\mathrm{a}}$ levels compared with those at low $t_{\mathrm{a}}$ levels. The OOA accounted for more than half of
OA, and showed much higher contribution at high $t_{\mathrm{a}}$ levels than at low $t_{\mathrm{a}}$ levels $(63 \%$ vs. $80 \%)$. Among them, MOOOA showed the largest enhancement, by a factor of 1.7 from 3.2 to $5.3 \mu \mathrm{g} \mathrm{m}^{-3}$ in absolute mass concentration and a factor of 1.6 from $29 \%$ to $48 \%$ in relative contribution, indicating the importance of MO-OOA in $\mathrm{PM}_{1}$ pollution at elevated $t_{\mathrm{a}}$ during the summertime. The contributions of LOOOA and IO-OOA were almost equal $(\sim 22 \%$ and $\sim 10 \%$, respectively) between low and high $t_{\mathrm{a}}$ levels, while the absolute mass concentrations were enhanced by a factor of $>1.1$ at high $t_{\mathrm{a}}$ levels. On the contrary, the absolute mass concentration of HOA decreased from 3.5 to $2.1 \mu \mathrm{g} \mathrm{m}^{-3}$ during high $t_{\mathrm{a}}$ periods, indicating a negative effect of $t_{\mathrm{a}}$ on the accumulation of HOA. The effects of dilution and evaporation might also be another reason for the lower HOA contribution and concentration, which tended to be observed at higher temperature conditions and/or in the afternoon with the higher planetary boundary layer (PBL) (Fig. S9).

\subsection{Role of photochemical aging in OA evolution}

The role of $t_{\mathrm{a}}$ in the evolution of OA during the summertime was further examined. Figure 6 shows the variations of $\mathrm{H} / \mathrm{C}$, $\mathrm{O} / \mathrm{C}, \mathrm{N} / \mathrm{C}, \mathrm{S} / \mathrm{C}, \mathrm{OM} / \mathrm{OC}$, and OSc as a function of $t_{\mathrm{a}}$. All of these elemental ratios were determined from $\mathrm{W}$ mode due to its higher resolution. And all except $\mathrm{H} / \mathrm{C}$ increased with the increase in $t_{\mathrm{a}}$. The decrease in $\mathrm{H} / \mathrm{C}$ was related to the decreased contribution of HOA (Fig. 5), since HOA had the highest $\mathrm{H} / \mathrm{C}$ among these four OA factors (Fig. S4). In contrast to $\mathrm{H} / \mathrm{C}, \mathrm{O} / \mathrm{C}$ and $\mathrm{OM} / \mathrm{OC}$ increased from 0.52 to 0.77 and 1.88 to 2.20 with the increase in $t_{\mathrm{a}}$, respectively. Moreover, a high correlation coefficient between OM/OC and O/C was observed $\left(R^{2}=0.997\right.$, Fig. S15 in the Supplement). These results suggest that OA was highly oxidized due to the progress of atmospheric photochemical aging. Meanwhile, the analogous variation between $\mathrm{OSc}$ and $\mathrm{O} / \mathrm{C}$ confirmed the high oxidation state of $\mathrm{OA}$, since both are metrics of the oxidation degree of OA (Kroll et al., 2011). As for the variation of N/C and S/C, they presented a slight increase trend with the increase in $t_{\mathrm{a}}$. This indicated that photochemical processes could contribute to the formation of $\mathrm{N}$-containing and $\mathrm{S}$-containing organics, which is consistent with the fact that both of them are the important products of gas-phase oxidation of VOCs and have also been detected in SOA (Farmer et al., 2010; Chen et al., 2019c, d).

The binned $\mathrm{H} / \mathrm{C}$ and $\mathrm{O} / \mathrm{C}$ as a function of $t_{\mathrm{a}}$ are given in Fig. 7. The fitted slope of -0.74 is similar to those reported in both field observations and laboratory simulations on the photochemical aging of anthropogenic primary OA or biomass burning OA (Chen et al., 2015). This slope can be obtained by a combination of the simultaneous addition of both alcohol $($ slope $=0)$ and carbonyl (slope $=-2$ ) functional groups, or the addition of carboxylic acid with (slope $=-0.5$ ) and without (slope $=-1$ ) fragmentation (Peng et al., 2016; Chen et al., 2015; Ng et al., 2011; 

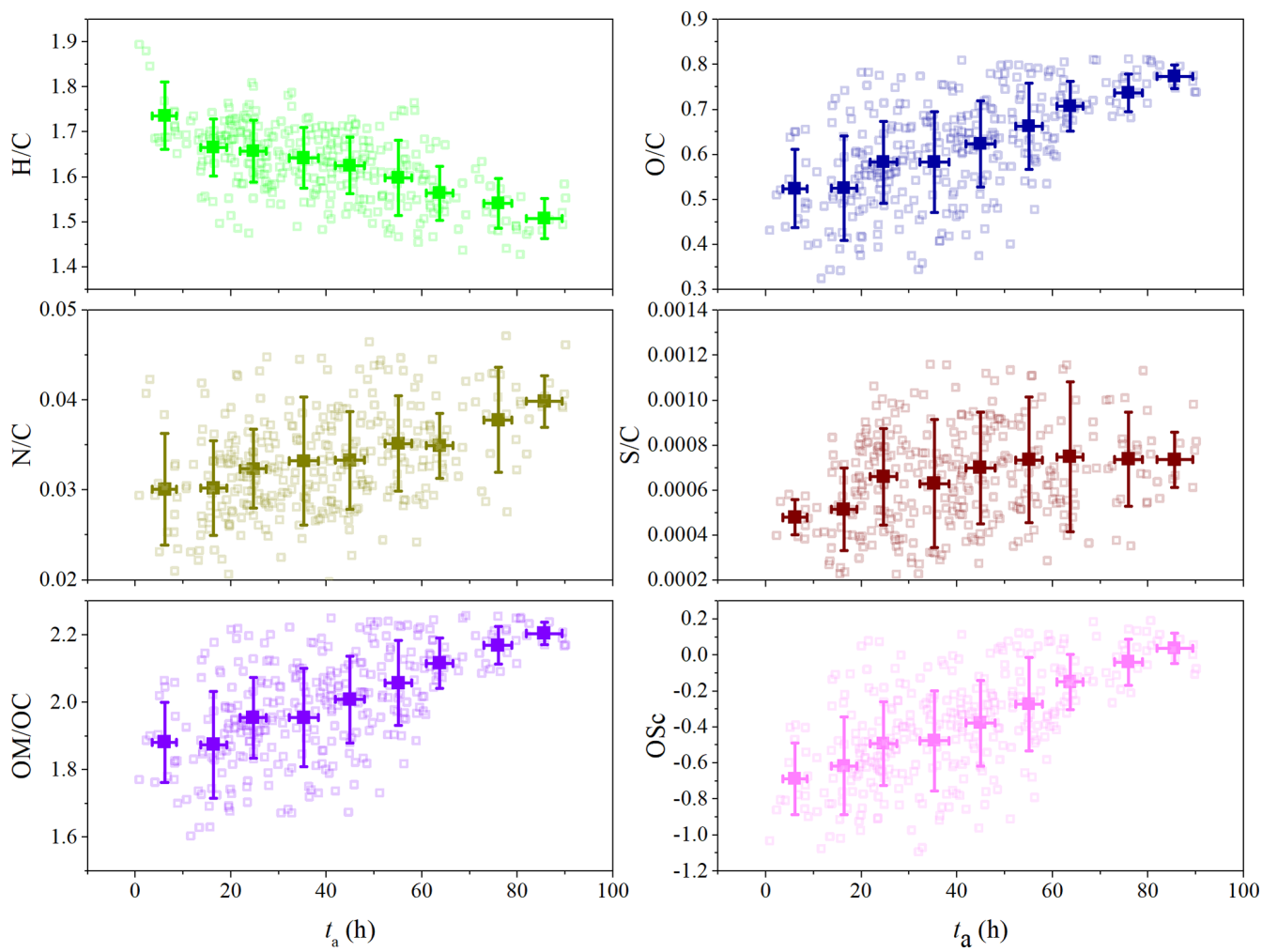

Figure 6. Variations of $\mathrm{H} / \mathrm{C}, \mathrm{O} / \mathrm{C}, \mathrm{N} / \mathrm{C}, \mathrm{S} / \mathrm{C}, \mathrm{OM} / \mathrm{OC}$, and $\mathrm{OSc}$ as a function of $t_{\mathrm{a}}$. The data are binned according to the value of $t_{\mathrm{a}}(10 \mathrm{~h}$ increments).

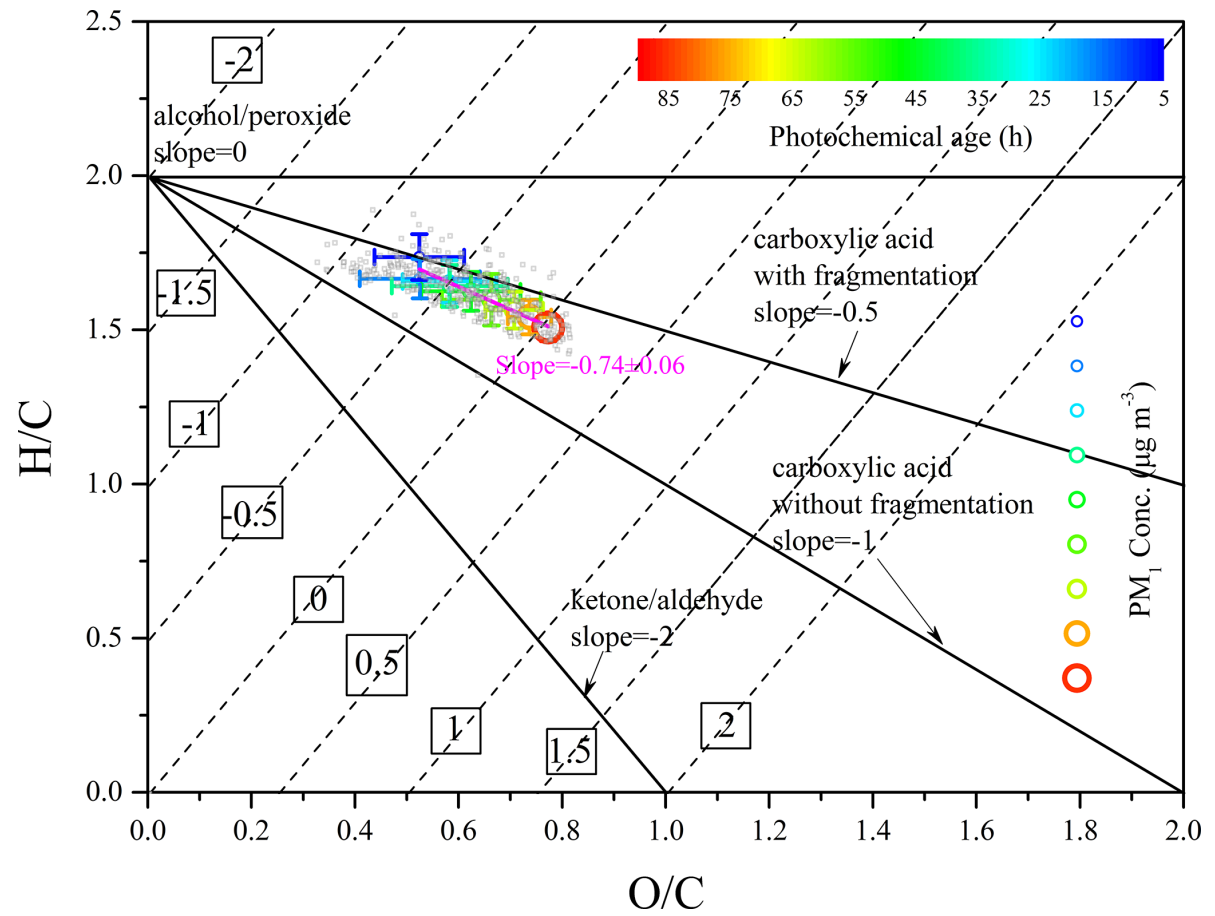

Figure 7. Van Krevelen diagram during this field observation. The data are binned according to the value of $t_{\mathrm{a}}(10 \mathrm{~h}$ increment) and color coded by $t_{\mathrm{a}}$. The elemental composition of OA was fitted with a slope of $-0.74\left(R^{2}=0.95\right)$. 
Heald et al., 2010). Additionally, as $t_{\mathrm{a}}$ increased, the OA evolved from the top-left region to the bottom-right region of the Van Krevelen diagram, accompanied by a decrease in $\mathrm{H} / \mathrm{C}$ and increase in $\mathrm{O} / \mathrm{C}$. This further indicated that the evolution process of OA was from less oxidized to more aged as the atmospheric photochemical aging progressed, leading to higher $\mathrm{PM}_{1}$ concentrations.

\section{Conclusions}

In this study, a summertime field observation mainly based on the Aerodyne HR-ToF-AMS was carried out to characterize NR-PM 1 in a southern suburb of Beijing from 25 July to 21 August 2019. The role of photochemical age $\left(t_{\mathrm{a}}\right)$ in aerosol formation and composition was analyzed. During this period, the averaged NR-PM 1 concentration was $19.3 \pm 11.3 \mu \mathrm{g} \mathrm{m}^{-3}$. For NR-PM 1 , OA was the dominant species $(48 \%-57 \%)$, followed by sulfate $(19 \%-27 \%)$ and nitrate $(10 \%-12 \%)$ at different $t_{\mathrm{a}}$ levels. Higher $\mathrm{PM}_{1}$ concentrations were observed at longer $t_{\mathrm{a}}$. Meanwhile, with the increase in $t_{\mathrm{a}}$, the normalized ratios of NR-PM $\mathrm{PM}_{1}$ species and OA factors to HOA were greatly enhanced by a factor of $>5$, especially for OA, sulfate, and MO-OOA. The total NR-PM 1 presented the largest average increase rate of $0.8 \mu \mathrm{g} \mathrm{m}^{-3} \mathrm{~h}^{-1}$, followed by sulfate $\left(0.4 \mu \mathrm{g} \mathrm{m}^{-3} \mathrm{~h}^{-1}\right)$ and MO-OOA $\left(0.3 \mu \mathrm{g} \mathrm{m}^{-3} \mathrm{~h}^{-1}\right)$. As $t_{\mathrm{a}}$ increased from 24.4 to $57.5 \mathrm{~h}$, the relative contribution of MO-OOA presented the most obvious promotion from $29 \%$ to $48 \%$, suggesting the significance of more oxidized OA, which mainly originates from the photo-oxidation of VOCs, in $\mathrm{PM}_{1}$ pollution during the summertime with strong solar radiation. The evolution of OA was also greatly affected by $t_{\mathrm{a}}$, decreased $\mathrm{H} / \mathrm{C}$ and increased $\mathrm{O} / \mathrm{C}$ could be found as $t_{\mathrm{a}}$ increased, along with the larger $\mathrm{OSc}$ and $\mathrm{OM} / \mathrm{OC}$, indicating that $\mathrm{OA}$ went from less oxidized to more aged with the progression of atmospheric photochemical aging, further leading to the higher $\mathrm{PM}_{1}$ concentration. Our results suggested that the atmospheric photochemical aging process is a crucial factor resulting in the $\mathrm{PM}_{1}$ pollution in summertime, especially for the formation and evolution of SOA. Previous studies have indicated that $\mathrm{NO}_{x}$ is a highly active species and has a great effect on the source of the main oxidants (e.g., $\mathrm{OH}, \mathrm{O}_{3}$, and $\mathrm{NO}_{3}$ ) (Seinfeld and Pandis, 2016). VOCs, as the crucial precursors of SOA, are derived from a wealth of sources, as well as lack effective control methods relative to other precursors. Meanwhile, the relative change in emissions of VOCs has also been estimated to be increased by $+11 \%$, while other precursors (mainly $\mathrm{SO}_{2}$ ) decreased during the period of 2010-2017 (Zheng et al., 2018). The relative increase in VOCs would lead to the increased contribution of SOA in $\mathrm{PM}_{1}$. Therefore, $\mathrm{NO}_{x}$ and VOCs, mainly from vehicle-related emissions (Liu et al., 2019a; Qin et al., 2017), should be strictly controlled to lower the atmospheric oxidation capacity characterized by $\mathrm{OH}$ exposure dose to further ease the PM pollution in sum- mertime. Meanwhile, more attention should be paid to the non-transportation sources, including heating (Cheng et al., 2018), cooking (H. Wang et al., 2018), asphalt-related emissions (Khare et al., 2020), and volatile chemical products (McDonald et al., 2018), which have been reported to be non-negligible contributors to ambient VOCs, and played a dominate role in the photochemistry of urban environments, especially for SOA formation.

Considering that there would be differences in the formation and evolution of $\mathrm{PM}_{1}$ between different seasons, and few field observations have been conducted in suburban areas of Beijing, further work should be carried out to shed light on the seasonal variations of $\mathrm{PM}_{1}$ and their formation and evolution mechanisms in different seasons in suburban areas. Additionally, the detailed role of photochemical age $\left(t_{\mathrm{a}}\right)$ in the formation of the secondary gaseous pollutant $\mathrm{O}_{3}$, as well as their relationship in different seasons, should also be of concern because $\mathrm{O}_{3}$ has become the primary air pollutant, especially in summertime.

Data availability. The experimental data are available upon request to the corresponding authors.

Supplement. The supplement related to this article is available online at: https://doi.org/10.5194/acp-21-1341-2021-supplement.

Author contributions. HH, YM, YL, and QM designed this field observation. TC, JL, and QM conducted the measurements and data analyses. TC, JL, QM, BC, PZ, CZ, and YL interpreted and discussed the data results. TC wrote the paper with input from all coauthors. All authors contributed to the final paper.

Competing interests. The authors declare that they have no conflict of interest.

Acknowledgements. The authors are grateful to all of the workers that provided their support during this field observation. The authors acknowledge the National Natural Science Foundation of China (21922610, 22006152, 21876185, 91744205, and 41877304); the Youth Innovation Promotion Association, CAS (2018055, 2018060, and 2017064); and the Young Talent Project of the Center for Excellence in Regional Atmospheric Environment, CAS (CERAE201801). The authors would also like to thank Ms. Qingcai Feng for her help editing this paper.

Financial support. This research has been supported by the National Natural Science Foundation of China (grant nos. 21922610, 21876185, 91744205, and 41877304) and the Chinese Academy of Sciences (grant nos. 2018055, 2018060, 2017064, and CERAE201801). 
Review statement. This paper was edited by Roya Bahreini and reviewed by two anonymous referees.

\section{References}

Aiken, A. C., Salcedo, D., Cubison, M. J., Huffman, J. A., DeCarlo, P. F., Ulbrich, I. M., Docherty, K. S., Sueper, D., Kimmel, J. R., Worsnop, D. R., Trimborn, A., Northway, M., Stone, E. A., Schauer, J. J., Volkamer, R. M., Fortner, E., de Foy, B., Wang, J., Laskin, A., Shutthanandan, V., Zheng, J., Zhang, R., Gaffney, J., Marley, N. A., Paredes-Miranda, G., Arnott, W. P., Molina, L. T., Sosa, G., and Jimenez, J. L.: Mexico City aerosol analysis during MILAGRO using high resolution aerosol mass spectrometry at the urban supersite (T0) - Part 1: Fine particle composition and organic source apportionment, Atmos. Chem. Phys., 9, 6633-6653, https://doi.org/10.5194/acp-9-6633-2009, 2009.

An, Z., Huang, R.-J., Zhang, R., Tie, X., Li, G., Cao, J., Zhou, W., Shi, Z., Han, Y., Gu, Z., and Ji, Y.: Severe haze in northern China: A synergy of anthropogenic emissions and atmospheric processes, P. Natl. Acad. Sci. USA, 116, 8657-8666, https://doi.org/10.1073/pnas.1900125116, 2019.

Atkinson, R. and Arey, J.: Atmospheric degradation of volatile organic compounds, Chem. Rev., 103, 4605-4638, https://doi.org/10.1021/cr0206420, 2003.

Canagaratna, M. R., Jimenez, J. L., Kroll, J. H., Chen, Q., Kessler, S. H., Massoli, P., Hildebrandt Ruiz, L., Fortner, E., Williams, L. R., Wilson, K. R., Surratt, J. D., Donahue, N. M., Jayne, J. T., and Worsnop, D. R.: Elemental ratio measurements of organic compounds using aerosol mass spectrometry: characterization, improved calibration, and implications, Atmos. Chem. Phys., 15, 253-272, https://doi.org/10.5194/acp-15-253-2015, 2015.

Chen, Q., Heald, C. L., Jimenez, J. L., Canagaratna, M. R., Zhang, Q., He, L.-Y., Huang, X.-F., Campuzano-Jost, P., Palm, B. B., Poulain, L., Kuwata, M., Martin, S. T., Abbatt, J. P. D., Lee, A. K. Y., and Liggio, J.: Elemental composition of organic aerosol: The gap between ambient and laboratory measurements, Geophys. Res. Lett., 42, 4182-4189, https://doi.org/10.1002/2015g1063693, 2015

Chen, T., Chu, B., Ge, Y., Zhang, S., Ma, Q., He, H., and Li, S.-M.: Enhancement of aqueous sulfate formation by the coexistence of $\mathrm{NO}_{2} / \mathrm{NH}_{3}$ under high ionic strengths in aerosol water, Environ. Pollut., 252, 236-244, https://doi.org/10.1016/j.envpol.2019.05.119, 2019a.

Chen, T., Liu, Y., Chu, B., Liu, C., Liu, J., Ge, Y., Ma, Q., Ma, J., and He, H.: Differences of the oxidation process and secondary organic aerosol formation at low and high precursor concentrations, J. Environ. Sci., 79, 256-263, https://doi.org/10.1016/j.jes.2018.11.011, 2019b.

Chen, T., Liu, Y., Liu, C., Liu, J., Chu, B., and He, H.: Important role of aromatic hydrocarbons in SOA formation from unburned gasoline vapor, Atmos. Environ., 201, 101-109, https://doi.org/10.1016/j.atmosenv.2019.01.001, 2019c.

Chen, T., Liu, Y., Ma, Q., Chu, B., Zhang, P., Liu, C., Liu, J., and He, H.: Significant source of secondary aerosol: formation from gasoline evaporative emissions in the presence of $\mathrm{SO}_{2}$ and $\mathrm{NH}_{3}$, Atmos. Chem. Phys., 19, 8063-8081, https://doi.org/10.5194/acp-19-8063-2019, 2019d.
Chen, T., Liu, J., Liu, Y., Ma, Q., Ge, Y., Zhong, C., Jiang, H., Chu, B., Zhang, P., Ma, J., Liu, P., Wang, Y., $\mathrm{Mu}, \mathrm{Y}$. , and $\mathrm{He}, \mathrm{H}$. : Chemical characterization of submicron aerosol in summertime Beijing: A case study in southern suburbs in 2018, Chemosphere, 247, 125918, https://doi.org/10.1016/j.chemosphere.2020.125918, 2020.

Cheng, J., Zhang, Y., Wang, T., Xu, H., Norris, P., and Pan, W.-P.: Emission of volatile organic compounds (VOCs) during coal combustion at different heating rates, Fuel, 225, 554-562, https://doi.org/10.1016/j.fuel.2018.03.185, 2018.

Cheng, Y., Zheng, G., Wei, C., Mu, Q., Zheng, B., Wang, Z., Gao, M., Zhang, Q., He, K., Carmichael, G., Pöschl, U., and Su, H.: Reactive nitrogen chemistry in aerosol water as a source of sulfate during haze events in China, Sci. Adv., 2, e1601530, https://doi.org/10.1126/sciadv.1601530, 2016.

Chu, B., Liu, Y., Ma, Q., Ma, J., He, H., Wang, G., Cheng, S., and Wang, X.: Distinct potential aerosol masses under different scenarios of transport at a suburban site of Beijing, J. Environ. Sci., 39, 52-61, https://doi.org/10.1016/j.jes.2015.11.003, 2016.

Chu, B., Dada, L., Liu, Y., Yao, L., Wang, Y., Du, W., Cai, J., Dällenbach, K. R., Chen, X., Simonen, P., Zhou, Y., Deng, C., Fu, Y., Yin, R., Li, H., He, X.-C., Feng, Z., Yan, C., Kangasluoma, J., Bianchi, F., Jiang, J., Kujansuu, J., Kerminen, V.-M., Petäjä, T., He, H., and Kulmala, M.: Particle growth with photochemical age from new particle formation to haze in the winter of Beijing, China, Sci. Total Environ., 753, 142207, https://doi.org/10.1016/j.scitotenv.2020.142207, 2021.

Davidson, C. I., Phalen, R. F., and Solomon, P. A.: Airborne particulate matter and human health: a review, Aerosol Sci. Tech., 39, 737-749, https://doi.org/10.1080/02786820500191348, 2005.

de Gouw, J. A., Middlebrook, A. M., Warneke, C., Goldan, P. D., Kuster, W. C., Roberts, J. M., Fehsenfeld, F. C., Worsnop, D. R., Canagaratna, M. R., Pszenny, A. A. P., Keene, W. C., Marchewka, M., Bertman, S. B., and Bates, T. S.: Budget of organic carbon in a polluted atmosphere: Results from the New England Air Quality Study in 2002, J. Geophys. Res., 110, https://doi.org/10.1029/2004jd005623, 2005.

de Gouw, J. A., Gilman, J. B., Kim, S. W., Lerner, B. M., IsaacmanVanWertz, G., McDonald, B. C., Warneke, C., Kuster, W. C., Lefer, B. L., Griffith, S. M., Dusanter, S., Stevens, P. S., and Stutz, J.: Chemistry of Volatile Organic Compounds in the Los Angeles basin: Nighttime Removal of Alkenes and Determination of Emission Ratios, J. Geophys. Res.-Atmos., 122, 1184311861, https://doi.org/10.1002/2017jd027459, 2017.

DeCarlo, P. F., Kimmel, J. R., Trimborn, A., Northway, M. J., Jayne, J. T., Aiken, A. C., Gonin, M., Fuhrer, K., Horvath, T., Docherty, K. S., Worsnop, D. R., and Jimenez, J. L.: Field-deployable, high-resolution, time-of-flight aerosol mass spectrometer, Anal. Chem., 78, 8281-8289, https://doi.org/10.1021/ac061249n, 2006.

DeCarlo, P. F., Dunlea, E. J., Kimmel, J. R., Aiken, A. C., Sueper, D., Crounse, J., Wennberg, P. O., Emmons, L., Shinozuka, Y., Clarke, A., Zhou, J., Tomlinson, J., Collins, D. R., Knapp, D., Weinheimer, A. J., Montzka, D. D., Campos, T., and Jimenez, J. L.: Fast airborne aerosol size and chemistry measurements above Mexico City and Central Mexico during the MILAGRO campaign, Atmos. Chem. Phys., 8, 4027-4048, https://doi.org/10.5194/acp-8-4027-2008, 2008. 
DeCarlo, P. F., Ulbrich, I. M., Crounse, J., de Foy, B., Dunlea, E. J., Aiken, A. C., Knapp, D., Weinheimer, A. J., Campos, T., Wennberg, P. O., and Jimenez, J. L.: Investigation of the sources and processing of organic aerosol over the Central Mexican Plateau from aircraft measurements during MILAGRO, Atmos. Chem. Phys., 10, 5257-5280, https://doi.org/10.5194/acp10-5257-2010, 2010.

Docherty, K. S., Aiken, A. C., Huffman, J. A., Ulbrich, I. M., DeCarlo, P. F., Sueper, D., Worsnop, D. R., Snyder, D. C., Peltier, R. E., Weber, R. J., Grover, B. D., Eatough, D. J., Williams, B. J., Goldstein, A. H., Ziemann, P. J., and Jimenez, J. L.: The 2005 Study of Organic Aerosols at Riverside (SOAR-1): instrumental intercomparisons and fine particle composition, Atmos. Chem. Phys., 11, 12387-12420, https://doi.org/10.5194/acp-11-123872011, 2011.

Draxier, R. R. and Hess, G. D.: An overview of the HYSPLIT_4 modelling system for trajectories, dispersion and deposition, Aust. Meteorol. Mag., 47, 295-308, 1998.

Drewnick, F., Hings, S. S., DeCarlo, P., Jayne, J. T., Gonin, M., Fuhrer, K., Weimer, S., Jimenez, J. L., Demerjian, K. L., Borrmann, S., and Worsnop, D. R.: A new time-of-flight aerosol mass spectrometer (TOF-AMS) - instrument description and first field deployment, Aerosol Sci. Tech., 39, 637-658, https://doi.org/10.1080/02786820500182040, 2005.

Duan, J., Huang, R.-J., Lin, C., Dai, W., Wang, M., Gu, Y., Wang, Y., Zhong, H., Zheng, Y., Ni, H., Dusek, U., Chen, Y., Li, Y., Chen, Q., Worsnop, D. R., O'Dowd, C. D., and Cao, J.: Distinctions in source regions and formation mechanisms of secondary aerosol in Beijing from summer to winter, Atmos. Chem. Phys., 19, 10319-10334, https://doi.org/10.5194/acp-19-103192019, 2019.

Duan, J., Huang, R.-J., Li, Y., Chen, Q., Zheng, Y., Chen, Y., Lin, C., Ni, H., Wang, M., Ovadnevaite, J., Ceburnis, D., Chen, C., Worsnop, D. R., Hoffmann, T., O’Dowd, C., and Cao, J.: Summertime and wintertime atmospheric processes of secondary aerosol in Beijing, Atmos. Chem. Phys., 20, 3793-3807, https://doi.org/10.5194/acp-20-3793-2020, 2020.

Elser, M., Huang, R.-J., Wolf, R., Slowik, J. G., Wang, Q., Canonaco, F., Li, G., Bozzetti, C., Daellenbach, K. R., Huang, Y., Zhang, R., Li, Z., Cao, J., Baltensperger, U., El-Haddad, I., and Prévôt, A. S. H.: New insights into $\mathrm{PM}_{2.5}$ chemical composition and sources in two major cities in China during extreme haze events using aerosol mass spectrometry, Atmos. Chem. Phys., 16, 3207-3225, https://doi.org/10.5194/acp-16-3207-2016, 2016.

Fan, Y., Liu, C.-Q., Li, L., Ren, L., Ren, H., Zhang, Z., Li, Q., Wang, S., Hu, W., Deng, J., Wu, L., Zhong, S., Zhao, Y., Pavuluri, C. M., Li, X., Pan, X., Sun, Y., Wang, Z., Kawamura, K., Shi, Z., and $\mathrm{Fu}, \mathrm{P} . \mathrm{L}$ Large contributions of biogenic and anthropogenic sources to fine organic aerosols in Tianjin, North China, Atmos. Chem. Phys., 20, 117-137, https://doi.org/10.5194/acp-20-1172020, 2020.

Farmer, D. K., Matsunaga, A., Docherty, K. S., Surratt, J. D., Seinfeld, J. H., Ziemann, P. J., and Jimenez, J. L.: Response of an aerosol mass spectrometer to organonitrates and organosulfates and implications for atmospheric chemistry, P. Natl. Acad. Sci. USA, 107, 6670-6675, https://doi.org/10.1073/pnas.0912340107, 2010.

Feng, T., Zhao, S., Bei, N., Wu, J., Liu, S., Li, X., Liu, L., Qian, Y., Yang, Q., Wang, Y., Zhou, W., Cao, J., and Li, G.: Sec- ondary organic aerosol enhanced by increasing atmospheric oxidizing capacity in Beijing-Tianjin-Hebei (BTH), China, Atmos. Chem. Phys., 19, 7429-7443, https://doi.org/10.5194/acp19-7429-2019, 2019.

Fu, P., Kawamura, K., Kanaya, Y., and Wang, Z.: Contributions of biogenic volatile organic compounds to the formation of secondary organic aerosols over Mt. Tai, Central East China, Atmos. Environ., 44, 4817-4826, https://doi.org/10.1016/j.atmosenv.2010.08.040, 2010.

Fu, P., Kawamura, K., Chen, J., and Miyazaki, Y.: Secondary Production of Organic Aerosols from Biogenic VOCs over Mt. Fuji, Japan, Environ. Sci. Technol., 48, 8491-8497, https://doi.org/10.1021/es500794d, 2014.

Ge, X., Li, L., Chen, Y., Chen, H., Wu, D., Wang, J., Xie, X., Ge, S., Ye, Z., Xu, J., and Chen, M.: Aerosol characteristics and sources in Yangzhou, China resolved by offline aerosol mass spectrometry and other techniques, Environ. Pollut., 225, 74-85, https://doi.org/10.1016/j.envpol.2017.03.044, 2017.

Gelencsér, A., Siszler, K., and Hlavay, J.: Toluene-Benzene Concentration Ratio as a Tool for Characterizing the Distance from Vehicular Emission Sources, Environ. Sci. Technol., 31, 28692872, https://doi.org/10.1021/es970004c, 1997.

Guo, S., Hu, M., Zamora, M. L., Peng, J., Shang, D., Zheng, J., Du, Z., Wu, Z., Shao, M., Zeng, L., Molina, M. J., and Zhang, R.: Elucidating severe urban haze formation in China, P. Natl. Acad. Sci. USA, 111, 17373-17378, https://doi.org/10.1073/pnas.1419604111, 2014.

Hallquist, M., Wenger, J. C., Baltensperger, U., Rudich, Y., Simpson, D., Claeys, M., Dommen, J., Donahue, N. M., George, C., Goldstein, A. H., Hamilton, J. F., Herrmann, H., Hoffmann, T., Iinuma, Y., Jang, M., Jenkin, M. E., Jimenez, J. L., Kiendler-Scharr, A., Maenhaut, W., McFiggans, G., Mentel, Th. F., Monod, A., Prévôt, A. S. H., Seinfeld, J. H., Surratt, J. D., Szmigielski, R., and Wildt, J.: The formation, properties and impact of secondary organic aerosol: current and emerging issues, Atmos. Chem. Phys., 9, 5155-5236, https://doi.org/10.5194/acp9-5155-2009, 2009.

Hayes, P. L., Ortega, A. M., Cubison, M. J., Froyd, K. D., Zhao, Y., Cliff, S. S., Hu, W. W., Toohey, D. W., Flynn, J. H., Lefer, B. L., Grossberg, N., Alvarez, S., Rappenglück, B., Taylor, J. W., Allan, J. D., Holloway, J. S., Gilman, J. B., Kuster, W. C., de Gouw, J. A., Massoli, P., Zhang, X., Liu, J., Weber, R. J., Corrigan, A. L., Russell, L. M., Isaacman, G., Worton, D. R., Kreisberg, N. M., Goldstein, A. H., Thalman, R., Waxman, E. M., Volkamer, R., Lin, Y. H., Surratt, J. D., Kleindienst, T. E., Offenberg, J. H., Dusanter, S., Griffith, S., Stevens, P. S., Brioude, J., Angevine, W. M., and Jimenez, J. L.: Organic aerosol composition and sources in Pasadena, California, during the 2010 CalNex campaign, J. Geophys. Res.-Atmos., 118, 9233-9257, https://doi.org/10.1002/jgrd.50530, 2013.

Heald, C. L., Kroll, J. H., Jimenez, J. L., Docherty, K. S., DeCarlo, P. F., Aiken, A. C., Chen, Q., Martin, S. T., Farmer, D. K., and Artaxo, P.: A simplified description of the evolution of organic aerosol composition in the atmosphere, Geophys. Res. Lett., 37, L08803, https://doi.org/10.1029/2010GL042737, 2010.

Herndon, S. C., Onasch, T. B., Wood, E. C., Kroll, J. H., Canagaratna, M. R., Jayne, J. T., Zavala, M. A., Knighton, W. B., Mazzoleni, C., Dubey, M. K., Ulbrich, I. M., Jimenez, J. L., Seila, R., de Gouw, J. A., de Foy, B., Fast, J., Molina, L. T., 
Kolb, C. E., and Worsnop, D. R.: Correlation of secondary organic aerosol with odd oxygen in Mexico City, Geophys. Res. Lett., 35, https://doi.org/10.1029/2008GL034058, 2008.

Herrmann, H., Schaefer, T., Tilgner, A., Styler, S. A., Weller, C., Teich, M., and Otto, T.: Tropospheric aqueousphase chemistry: kinetics, mechanisms, and its coupling to a changing gas phase, Chem. Rev., 115, 4259-4334, https://doi.org/10.1021/cr500447k, 2015.

Hu, W., Hu, M., Hu, W., Jimenez, J. L., Yuan, B., Chen, W., Wang, M., Wu, Y., Chen, C., Wang, Z., Peng, J., Zeng, L., and Shao, M.: Chemical composition, sources, and aging process of submicron aerosols in Beijing: Contrast between summer and winter, J. Geophys. Res.-Atmos., 121, 1955-1977, https://doi.org/10.1002/2015JD024020, 2016.

Hu, W., Hu, M., Hu, W.-W., Zheng, J., Chen, C., Wu, Y., and Guo, S.: Seasonal variations in high time-resolved chemical compositions, sources, and evolution of atmospheric submicron aerosols in the megacity Beijing, Atmos. Chem. Phys., 17, 9979-10000, https://doi.org/10.5194/acp-17-9979-2017, 2017.

Hua, Y., Wang, S., Jiang, J., Zhou, W., Xu, Q., Li, X., Liu, B., Zhang, D., and Zheng, M.: Characteristics and sources of aerosol pollution at a polluted rural site southwest in Beijing, China, Sci. Total Environ., 626, 519-527, https://doi.org/10.1016/j.scitotenv.2018.01.047, 2018.

Huang, D. D., Li, Y. J., Lee, B. P., and Chan, C. K.: Analysis of organic sulfur compounds in atmospheric aerosols at the HKUST supersite in Hong Kong using HR-ToF-AMS, Environ. Sci. Technol., 49, 3672-3679, https://doi.org/10.1021/es5056269, 2015.

Huang, R.-J., Zhang, Y., Bozzetti, C., Ho, K.-F., Cao, J.-J., Han, Y., Daellenbach, K. R., Slowik, J. G., Platt, S. M., Canonaco, F., Zotter, P., Wolf, R., Pieber, S. M., Bruns, E. A., Crippa, M., Ciarelli, G., Piazzalunga, A., Schwikowski, M., Abbaszade, G., SchnelleKreis, J., Zimmermann, R., An, Z., Szidat, S., Baltensperger, U., Haddad, I. E., and Prevot, A. S. H.: High secondary aerosol contribution to particulate pollution during haze events in China, Nature, 514, 218-222, https://doi.org/10.1038/nature13774, 2014.

Huang, R.-J., Wang, Y., Cao, J., Lin, C., Duan, J., Chen, Q., Li, Y., Gu, Y., Yan, J., Xu, W., Fröhlich, R., Canonaco, F., Bozzetti, C., Ovadnevaite, J., Ceburnis, D., Canagaratna, M. R., Jayne, J., Worsnop, D. R., El-Haddad, I., Prévôt, A. S. H., and O'Dowd, C. D.: Primary emissions versus secondary formation of fine particulate matter in the most polluted city (Shijiazhuang) in North China, Atmos. Chem. Phys., 19, 2283-2298, https://doi.org/10.5194/acp-19-2283-2019, 2019.

Huang, X.-F., He, L.-Y., Hu, M., Canagaratna, M. R., Sun, Y., Zhang, Q., Zhu, T., Xue, L., Zeng, L.-W., Liu, X.-G., Zhang, Y.-H., Jayne, J. T., Ng, N. L., and Worsnop, D. R.: Highly time-resolved chemical characterization of atmospheric submicron particles during 2008 Beijing Olympic Games using an Aerodyne High-Resolution Aerosol Mass Spectrometer, Atmos. Chem. Phys., 10, 8933-8945, https://doi.org/10.5194/acp-108933-2010, 2010.

IPCC: Climate Change 2013: The Physical Science Basis. Contribution of Working Group I to the Fifth Assessment Report of the Intergovernmental Panel on Climate Change, Cambridge University Press, Cambridge, UK and New York, NY, USA, 1535 pp., 2013.

Jimenez, J. L., Jayne, J. T., Shi, Q., Kolb, C. E., Worsnop, D. R., Yourshaw, I., Seinfeld, J. H., Flagan, R. C., Zhang, X., Smith,
K. A., Morris, J. W., and Davidovits, P.: Ambient aerosol sampling using the aerodyne aerosol mass spectrometer, J. Geophys. Res.-Atmos., 108, 8425, https://doi.org/10.1029/2001JD001213, 2003.

Kroll, J. H., Donahue, N. M., Jimenez, J. L., Kessler, S. H., Canagaratna, M. R., Wilson, K. R., Altieri, K. E., Mazzoleni, L. R., Wozniak, A. S., Bluhm, H., Mysak, E. R., Smith, J. D., Kolb, C. E., and Worsnop, D. R.: Carbon oxidation state as a metric for describing the chemistry of atmospheric organic aerosol, Nature Chem., 3, 133-139, https://doi.org/10.1038/nchem.948, 2011.

Khare, P., Machesky, J., Soto, R., He, M., Presto, A. A., and Gentner, D. R.: Asphalt-related emissions are a major missing nontraditional source of secondary organic aerosol precursors, Sci. Adv., 6, eabb9785, https://doi.org/10.1126/sciadv.abb9785, 2020.

Li, J., Liu, Q., Li, Y., Liu, T., Huang, D., Zheng, J., Zhu, W., Hu, M., Wu, Y., Lou, S., Hallquist, A. M., Hallquist, M., Chan, C. K., Canonaco, F., Prevot, A. S. H., Fung, J. C. H., Lau, A. K. H., and Yu, J. Z.: Characterization of Aerosol Aging Potentials at Suburban Sites in Northern and Southern China Utilizing a Potential Aerosol Mass (Go:PAM) Reactor and an Aerosol Mass Spectrometer, J. Geophys. Res.-Atmos., 124, 5629-5649, https://doi.org/10.1029/2018jd029904, 2019a.

Li, J., Cao, L., Gao, W., He, L., Yan, Y., Ji, D., Liu, Z., and Wang, Y.: Seasonal variations in the high time-resolved aerosol composition, sources, and chemical process of background submicron particles in North China Plain, Atmos. Chem. Phys. Discuss. [preprint], https://doi.org/10.5194/acp-2020-213, in review, 2020.

Li, K., Jacob, D. J., Liao, H., Shen, L., Zhang, Q., and Bates, K. H.: Anthropogenic drivers of 2013-2017 trends in summer surface ozone in China, P. Natl. Acad. Sci. USA, 116, 422-427, https://doi.org/10.1073/pnas.1812168116, 2019b.

Li, K., Jacob, D. J., Liao, H., Zhu, J., Shah, V., Shen, L., Bates, K. H., Zhang, Q., and Zhai, S.: A two-pollutant strategy for improving ozone and particulate air quality in China, Nat. Geosci., 12, 906-910, https://doi.org/10.1038/s41561-019-0464-x, 2019c.

Li, L., Ren, L., Ren, H., Yue, S., Xie, Q., Zhao, W., Kang, M., Li, J., Wang, Z., Sun, Y., and Fu, P.: Molecular Characterization and Seasonal Variation in Primary and Secondary Organic Aerosols in Beijing, China, J. Geophys. Res.-Atmos., 123, 12394-12412, https://doi.org/10.1029/2018jd028527, 2018a.

Li, Q., Zhang, L., Wang, T., Wang, Z., Fu, X., and Zhang, Q.: "New" Reactive Nitrogen Chemistry Reshapes the Relationship of Ozone to Its Precursors, Environ. Sci. Technol., 52, 2810 2818, https://doi.org/10.1021/acs.est.7b05771, 2018 b.

Li, Y. J., Lee, B. Y. L., Yu, J. Z., Ng, N. L., and Chan, C. K.: Evaluating the degree of oxygenation of organic aerosol during foggy and hazy days in Hong Kong using high-resolution time-of-flight aerosol mass spectrometry (HR-ToF-AMS), Atmos. Chem. Phys., 13, 8739-8753, https://doi.org/10.5194/acp13-8739-2013, 2013.

Li, Y. J., Lee, B. P., Su, L., Fung, J. C. H., and Chan, C. K.: Seasonal characteristics of fine particulate matter (PM) based on highresolution time-of-flight aerosol mass spectrometric (HR-ToFAMS) measurements at the HKUST Supersite in Hong Kong, Atmos. Chem. Phys., 15, 37-53, https://doi.org/10.5194/acp-1537-2015, 2015. 
Li, Y. J., Sun, Y., Zhang, Q., Li, X., Li, M., Zhou, Z., and Chan, C. K.: Real-time chemical characterization of atmospheric particulate matter in China: A review, Atmos. Environ., 158, 270-304, https://doi.org/10.1016/j.atmosenv.2017.02.027, 2017.

Liu, H., Qi, L., Liang, C., Deng, F., Man, H., and He, K.: How aging process changes characteristics of vehicle emissions? A review, Crit. Rev. Environ. Sci. Technol., 50, https://doi.org/10.1080/10643389.2019.1669402, 2019a.

Liu, J., Chu, B., Chen, T., Liu, C., Wang, L., Bao, X., and He, H.: Secondary organic aerosol formation from ambient air at an urban site in Beijing: effects of $\mathrm{OH}$ exposure and precursor concentrations, Environ. Sci. Technol., 52, 6834-6841, https://doi.org/10.1021/acs.est.7b05701, 2018.

Liu, M., Huang, X., Song, Y., Tang, J., Cao, J., Zhang, X., Zhang, Q., Wang, S., Xu, T., Kang, L., Cai, X., Zhang, H., Yang, F., Wang, H., Yu, J. Z., Lau, A. K. H., He, L., Huang, X., Duan, L., Ding, A., Xue, L., Gao, J., Liu, B., and Zhu, T.: Ammonia emission control in China would mitigate haze pollution and nitrogen deposition, but worsen acid rain, P. Natl. Acad. Sci. USA, 116, 7760-7765, https://doi.org/10.1073/pnas.1814880116, 2019b.

Liu, Q., Sun, Y., Hu, B., Liu, Z., Akio, S., and Wang, Y.: In situ measurement of $\mathrm{PM}_{1}$ organic aerosol in Beijing winter using a high-resolution aerosol mass spectrometer, Chinese Sci. Bull., 57, 819-826, https://doi.org/10.1007/s11434-011-4886-0, 2012.

Mao, J., Ren, X., Brune, W. H., Olson, J. R., Crawford, J. H., Fried, A., Huey, L. G., Cohen, R. C., Heikes, B., Singh, H. B., Blake, D. R., Sachse, G. W., Diskin, G. S., Hall, S. R., and Shetter, R. E.: Airborne measurement of $\mathrm{OH}$ reactivity during INTEX-B, Atmos. Chem. Phys., 9, 163-173, https://doi.org/10.5194/acp-9163-2009, 2009.

McDonald, B. C., de Gouw, J. A., Gilman, J. B., Jathar, S. H., Akherati, A., Cappa, C. D., Jimenez, J. L., Lee-Taylor, J., Hayes, P. L., McKeen, S. A., Cui, Y. Y., Kim, S.-W., Gentner, D. R., Isaacman-VanWertz, G., Goldstein, A. H., Harley, R. A., Frost, G. J., Roberts, J. M., Ryerson, T. B., and Trainer, M.: Volatile chemical products emerging as largest petrochemical source of urban organic emissions, Science, 359, 760-764, https://doi.org/10.1126/science.aaq0524, 2018.

McKeen, S. A., Liu, S. C., Hsie, E.-Y., Lin, X., Bradshaw, J. D., Smyth, S., Gregory, G. L., and Blake, D. R.: Hydrocarbon ratios during PEM-WEST A: A model perspective, J. Geophys. Res.Atmos., 101, 2087-2109, https://doi.org/10.1029/95jd02733, 1996.

Middlebrook, A. M., Bahreini, R., Jimenez, J. L., and Canagaratna, M. R.: Evaluation of composition-dependent collection efficiencies for the Aerodyne aerosol mass spectrometer using field data, Aerosol Sci. Tech., 46, 258-271, https://doi.org/10.1080/02786826.2011.620041, 2012.

Molina, M. J. and Molina, L. T.: Megacities and atmospheric pollution, J. Air Waste Manage., 54, 644-680, https://doi.org/10.1080/10473289.2004.10470936, 2004.

Nault, B. A., Campuzano-Jost, P., Day, D. A., Schroder, J. C., Anderson, B., Beyersdorf, A. J., Blake, D. R., Brune, W. H., Choi, Y., Corr, C. A., de Gouw, J. A., Dibb, J., DiGangi, J. P., Diskin, G. S., Fried, A., Huey, L. G., Kim, M. J., Knote, C. J., Lamb, K. D., Lee, T., Park, T., Pusede, S. E., Scheuer, E., Thornhill, K. L., Woo, J.-H., and Jimenez, J. L.: Secondary organic aerosol production from local emissions dominates the organic aerosol budget over Seoul, South Korea, during KORUS-AQ, Atmos. Chem.
Phys., 18, 17769-17800, https://doi.org/10.5194/acp-18-177692018, 2018.

Ng, N. L., Canagaratna, M. R., Jimenez, J. L., Chhabra, P. S., Seinfeld, J. H., and Worsnop, D. R.: Changes in organic aerosol composition with aging inferred from aerosol mass spectra, Atmos. Chem. Phys., 11, 6465-6474, https://doi.org/10.5194/acp11-6465-2011, 2011.

Paatero, P.: Least squares formulation of robust non-negative factor analysis, Chemometr. Intell. Lab., 37, 23-35, https://doi.org/10.1016/S0169-7439(96)00044-5, 1997.

Paatero, P. and Tapper, U.: Positive matrix factorization: a non-negative factor model with optimal utilization of error estimates of data values, Environmetrics, 5, 111-126, https://doi.org/10.1002/env.3170050203, 1994.

Parrish, D. D., Stohl, A., Forster, C., Atlas, E. L., Blake, D. R., Goldan, P. D., Kuster, W. C., and de Gouw, J. A.: Effects of mixing on evolution of hydrocarbon ratios in the troposphere, J. Geophys. Res.-Atmos., 112, https://doi.org/10.1029/2006jd007583, 2007.

Peng, J., Hu, M., Gong, Z., Tian, X., Wang, M., Zheng, J., Guo, Q., Cao, W., Lv, W., Hu, W., Wu, Z., and Guo, S.: Evolution of secondary inorganic and organic aerosols during transport: A case study at a regional receptor site, Environ. Pollut., 218, 794803, https://doi.org/10.1016/j.envpol.2016.08.003, 2016.

Pusede, S. E., Gentner, D. R., Wooldridge, P. J., Browne, E. C., Rollins, A. W., Min, K.-E., Russell, A. R., Thomas, J., Zhang, L., Brune, W. H., Henry, S. B., DiGangi, J. P., Keutsch, F. N., Harrold, S. A., Thornton, J. A., Beaver, M. R., St. Clair, J. M., Wennberg, P. O., Sanders, J., Ren, X., VandenBoer, T. C., Markovic, M. Z., Guha, A., Weber, R., Goldstein, A. H., and Cohen, R. C.: On the temperature dependence of organic reactivity, nitrogen oxides, ozone production, and the impact of emission controls in San Joaquin Valley, California, Atmos. Chem. Phys., 14, 3373-3395, https://doi.org/10.5194/acp-143373-2014, 2014.

Qin, Y. M., Li, Y. J., Wang, H., Lee, B. P. Y. L., Huang, D. D., and Chan, C. K.: Particulate matter (PM) episodes at a suburban site in Hong Kong: evolution of PM characteristics and role of photochemistry in secondary aerosol formation, Atmos. Chem. Phys., 16, 14131-14145, https://doi.org/10.5194/acp-16-141312016, 2016.

Qin, Y. M., Tan, H. B., Li, Y. J., Schurman, M. I., Li, F., Canonaco, F., Prévôt, A. S. H., and Chan, C. K.: Impacts of traffic emissions on atmospheric particulate nitrate and organics at a downwind site on the periphery of Guangzhou, China, Atmos. Chem. Phys., 17, 10245-10258, https://doi.org/10.5194/acp-17-102452017, 2017.

Schnell, J. L. and Prather, M. J.: Co-occurrence of extremes in surface ozone, particulate matter, and temperature over eastern North America, P. Natl. Acad. Sci. USA, 114, 2854-2859, https://doi.org/10.1073/pnas.1614453114, 2017.

Seinfeld, J. H. and Pandis, S. N.: Atmospheric chemistry and physics: from air pollution to climate change, John Wiley \& Sons, Hoboken, NJ, 2016.

Shi, Z., Vu, T., Kotthaus, S., Harrison, R. M., Grimmond, S., Yue, S., Zhu, T., Lee, J., Han, Y., Demuzere, M., Dunmore, R. E., Ren, L., Liu, D., Wang, Y., Wild, O., Allan, J., Acton, W. J., Barlow, J., Barratt, B., Beddows, D., Bloss, W. J., Calzolai, G., Carruthers, D., Carslaw, D. C., Chan, Q., Chatzidiakou, L., Chen, Y., Cril- 
ley, L., Coe, H., Dai, T., Doherty, R., Duan, F., Fu, P., Ge, B., Ge, M., Guan, D., Hamilton, J. F., He, K., Heal, M., Heard, D., Hewitt, C. N., Hollaway, M., Hu, M., Ji, D., Jiang, X., Jones, R., Kalberer, M., Kelly, F. J., Kramer, L., Langford, B., Lin, C., Lewis, A. C., Li, J., Li, W., Liu, H., Liu, J., Loh, M., Lu, K., Lucarelli, F., Mann, G., McFiggans, G., Miller, M. R., Mills, G., Monk, P., Nemitz, E., O'Connor, F., Ouyang, B., Palmer, P. I., Percival, C., Popoola, O., Reeves, C., Rickard, A. R., Shao, L., Shi, G., Spracklen, D., Stevenson, D., Sun, Y., Sun, Z., Tao, S., Tong, S., Wang, Q., Wang, W., Wang, X., Wang, X., Wang, Z., Wei, L., Whalley, L., Wu, X., Wu, Z., Xie, P., Yang, F., Zhang, Q., Zhang, Y., Zhang, Y., and Zheng, M.: Introduction to the special issue "In-depth study of air pollution sources and processes within Beijing and its surrounding region (APHH-Beijing)", Atmos. Chem. Phys., 19, 7519-7546, https://doi.org/10.5194/acp19-7519-2019, 2019.

Sun, J., Zhang, Q., Canagaratna, M. R., Zhang, Y., Ng, N. L., Sun, Y., Jayne, J. T., Zhang, X., Zhang, X., and Worsnop, D. R.: Highly time- and size-resolved characterization of submicron aerosol particles in Beijing using an Aerodyne Aerosol Mass Spectrometer, Atmos. Environ., 44, 131-140, https://doi.org/10.1016/j.atmosenv.2009.03.020, 2010.

Sun, P., Nie, W., Chi, X., Xie, Y., Huang, X., Xu, Z., Qi, X., Xu, Z., Wang, L., Wang, T., Zhang, Q., and Ding, A.: Two years of online measurement of fine particulate nitrate in the western Yangtze River Delta: influences of thermodynamics and $\mathrm{N}_{2} \mathrm{O}_{5}$ hydrolysis, Atmos. Chem. Phys., 18, 17177-17190, https://doi.org/10.5194/acp-18-17177-2018, 2018 a.

Sun, Y., Wang, Z., Dong, H., Yang, T., Li, J., Pan, X., Chen, P., and Jayne, J. T.: Characterization of summer organic and inorganic aerosols in Beijing, China with an Aerosol Chemical Speciation Monitor, Atmos. Environ., 51, 250-259, https://doi.org/10.1016/j.atmosenv.2012.01.013, 2012.

Sun, Y., Wang, Z., Fu, P., Jiang, Q., Yang, T., Li, J., and Ge, X.: The impact of relative humidity on aerosol composition and evolution processes during wintertime in Beijing, China, Atmos. Environ., 77, 927-934, https://doi.org/10.1016/j.atmosenv.2013.06.019, 2013a.

Sun, Y., Chen, C., Zhang, Y., Xu, W., Zhou, L., Cheng, X., Zheng, H., Ji, D., Li, J., Tang, X., Fu, P., and Wang, Z.: Rapid formation and evolution of an extreme haze episode in Northern China during winter 2015, Sci. Rep.-UK, 6, 27151, https://doi.org/10.1038/srep27151, 2016a.

Sun, Y., Du, W., Fu, P., Wang, Q., Li, J., Ge, X., Zhang, Q., Zhu, C., Ren, L., Xu, W., Zhao, J., Han, T., Worsnop, D. R., and Wang, Z.: Primary and secondary aerosols in Beijing in winter: sources, variations and processes, Atmos. Chem. Phys., 16, 8309-8329, https://doi.org/10.5194/acp-16-8309-2016, 2016b.

Sun, Y., Xu, W., Zhang, Q., Jiang, Q., Canonaco, F., Prévôt, A. S. H., Fu, P., Li, J., Jayne, J., Worsnop, D. R., and Wang, Z.: Source apportionment of organic aerosol from 2-year highly time-resolved measurements by an aerosol chemical speciation monitor in Beijing, China, Atmos. Chem. Phys., 18, 8469-8489, https://doi.org/10.5194/acp-18-8469-2018, 2018 b.

Sun, Y. L., Wang, Z. F., Fu, P. Q., Yang, T., Jiang, Q., Dong, H. B., Li, J., and Jia, J. J.: Aerosol composition, sources and processes during wintertime in Beijing, China, Atmos. Chem. Phys., 13, 4577-4592, https://doi.org/10.5194/acp-13-4577-2013, 2013 b.
Sun, Y. L., Jiang, Q., Wang, Z. F., Fu, P. Q., Li, J., Yang, T., and Yin, Y.: Investigation of the sources and evolution processes of severe haze pollution in Beijing in January 2013, J. Geophys. Res.Atmos., 119, 4380-4398, https://doi.org/10.1002/2014jd021641, 2014.

Sun, Y. L., Wang, Z. F., Du, W., Zhang, Q., Wang, Q. Q., Fu, P. Q., Pan, X. L., Li, J., Jayne, J., and Worsnop, D. R.: Longterm real-time measurements of aerosol particle composition in Beijing, China: seasonal variations, meteorological effects, and source analysis, Atmos. Chem. Phys., 15, 10149-10165, https://doi.org/10.5194/acp-15-10149-2015, 2015.

Tan, Z., Lu, K., Jiang, M., Su, R., Wang, H., Lou, S., Fu, Q., Zhai, C., Tan, Q., Yue, D., Chen, D., Wang, Z., Xie, S., Zeng, L., and Zhang, Y.: Daytime atmospheric oxidation capacity in four Chinese megacities during the photochemically polluted season: a case study based on box model simulation, Atmos. Chem. Phys., 19, 3493-3513, https://doi.org/10.5194/acp-193493-2019, 2019.

Tie, X., Huang, R.-J., Cao, J., Zhang, Q., Cheng, Y., Su, H., Chang, D., Poeschl, U., Hoffmann, T., Dusek, U., Li, G., Worsnop, D. R., and O'Dowd, C. D.: Severe Pollution in China Amplified by Atmospheric Moisture, Sci. Rep.-UK, 7, https://doi.org/10.1038/s41598-017-15909-1, 2017.

Ulbrich, I. M., Canagaratna, M. R., Zhang, Q., Worsnop, D. R., and Jimenez, J. L.: Interpretation of organic components from Positive Matrix Factorization of aerosol mass spectrometric data, Atmos. Chem. Phys., 9, 2891-2918, https://doi.org/10.5194/acp-92891-2009, 2009.

Wang, G., Zhang, R., Gomez, M. E., Yang, L., Levy Zamora, M., Hu, M., Lin, Y., Peng, J., Guo, S., Meng, J., Li, J., Cheng, C., Hu, T., Ren, Y., Wang, Y., Gao, J., Cao, J., An, Z., Zhou, W., Li, G., Wang, J., Tian, P., Marrero-Ortiz, W., Secrest, J., Du, Z., Zheng, J., Shang, D., Zeng, L., Shao, M., Wang, W., Huang, Y., Wang, Y., Zhu, Y., Li, Y., Hu, J., Pan, B., Cai, L., Cheng, Y., Ji, Y., Zhang, F., Rosenfeld, D., Liss, P. S., Duce, R. A., Kolb, C. E., and Molina, M. J.: Persistent sulfate formation from London Fog to Chinese haze, P. Natl. Acad. Sci. USA, 113, 13630-13635, https://doi.org/10.1073/pnas.1616540113, 2016.

Wang, H., Xiang, Z., Wang, L., Jing, S., Lou, S., Tao, S., Liu, J., Yu, M., Li, L., Lin, L., Chen, Y., Wiedensohler, A., and Chen, C.: Emissions of volatile organic compounds (VOCs) from cooking and their speciation: A case study for Shanghai with implications for China, Sci. Total Environ., 621, 1300-1309, https://doi.org/10.1016/j.scitotenv.2017.10.098, 2018.

Wang, Q., Sun, Y., Xu, W., Du, W., Zhou, L., Tang, G., Chen, C., Cheng, X., Zhao, X., Ji, D., Han, T., Wang, Z., Li, J., and Wang, Z.: Vertically resolved characteristics of air pollution during two severe winter haze episodes in urban Beijing, China, Atmos. Chem. Phys., 18, 2495-2509, https://doi.org/10.5194/acp18-2495-2018, 2018.

Wang, T., Xue, L., Brimblecombe, P., Lam, Y. F., Li, L., and Zhang, L.: Ozone pollution in China: A review of concentrations, meteorological influences, chemical precursors, and effects, Sci. Total Environ., 575, 1582-1596, https://doi.org/10.1016/j.scitotenv.2016.10.081, 2017.

Wang, Y. C., Huang, R. J., Ni, H. Y., Chen, Y., Wang, Q. Y., Li, G. H., Tie, X. X., Shen, Z. X., Huang, Y., Liu, S. X., Dong, W. M., Xue, P., Fröhlich, R., Canonaco, F., Elser, M., Daellenbach, K. R., Bozzetti, C., El Haddad, I., Prévôt, A. S. H., 
Canagaratna, M. R., Worsnop, D. R., and Cao, J. J.: Chemical composition, sources and secondary processes of aerosols in Baoji city of northwest China, Atmos. Environ., 158, 128-137, https://doi.org/10.1016/j.atmosenv.2017.03.026, 2017.

Wood, E. C., Canagaratna, M. R., Herndon, S. C., Onasch, T. B., Kolb, C. E., Worsnop, D. R., Kroll, J. H., Knighton, W. B., Seila, R., Zavala, M., Molina, L. T., DeCarlo, P. F., Jimenez, J. L., Weinheimer, A. J., Knapp, D. J., Jobson, B. T., Stutz, J., Kuster, W. C., and Williams, E. J.: Investigation of the correlation between odd oxygen and secondary organic aerosol in Mexico City and Houston, Atmos. Chem. Phys., 10, 8947-8968, https://doi.org/10.5194/acp-10-8947-2010, 2010.

Wu, Y., Ge, X., Wang, J., Shen, Y., Ye, Z., Ge, S., Wu, Y., Yu, H., and Chen, M.: Responses of secondary aerosols to relative humidity and photochemical activities in an industrialized environment during late winter, Atmos. Environ., 193, 66-78, https://doi.org/10.1016/j.atmosenv.2018.09.008, 2018.

Xie, Q., Li, Y., Yue, S., Su, S., Cao, D., Xu, Y., Chen, J., Tong, H., Su, H., Cheng, Y., Zhao, W., Hu, W., Wang, Z., Yang, T., Pan, X., Sun, Y., Wang, Z., Liu, C.-Q., Kawamura, K., Jiang, G., Shiraiwa, M., and Fu, P.: Increase of High Molecular Weight Organosulfate With Intensifying Urban Air Pollution in the Megacity Beijing, J. Geophys. Res.-Atmos., 125, e2019JD032200, https://doi.org/10.1029/2019jd032200, 2020.

Xu, J., Zhang, Q., Chen, M., Ge, X., Ren, J., and Qin, D.: Chemical composition, sources, and processes of urban aerosols during summertime in northwest China: insights from high-resolution aerosol mass spectrometry, Atmos. Chem. Phys., 14, 1259312611, https://doi.org/10.5194/acp-14-12593-2014, 2014.

Xu, Q., Wang, S., Jiang, J., Bhattarai, N., Li, X., Chang, X., Qiu, X., Zheng, M., Hua, Y., and Hao, J.: Nitrate dominates the chemical composition of $\mathrm{PM}_{2.5}$ during haze event in Beijing, China, Sci. Total Environ., 689, 1293-1303, https://doi.org/10.1016/j.scitotenv.2019.06.294, 2019a.

Xu, W., Han, T., Du, W., Wang, Q., Chen, C., Zhao, J., Zhang, Y., Li, J., Fu, P., Wang, Z., Worsnop, D. R., and Sun, Y.: Effects of aqueous-phase and photochemical processing on secondary organic aerosol formation and evolution in Beijing, China, Environ. Sci. Technol., 51, 762-770, https://doi.org/10.1021/acs.est.6b04498, 2017.
Xu, W., Sun, Y., Wang, Q., Zhao, J., Wang, J., Ge, X., Xie, C., Zhou, W., Du, W., Li, J., Fu, P., Wang, Z., Worsnop, D. R., and Coe, H.: Changes in aerosol chemistry from 2014 to 2016 in winter in Beijing: Insights from high-resolution aerosol mass spectrometry, J. Geophys. Res.-Atmos., 124, 1132-1147, https://doi.org/10.1029/2018jd029245, 2019b.

Ye, Z., Li, Q., Liu, J., Luo, S., Zhou, Q., Bi, C., Ma, S., Chen, Y., Chen, H., Li, L., and Ge, X.: Investigation of submicron aerosol characteristics in Changzhou, China: Composition, source, and comparison with co-collected $\mathrm{PM}_{2.5}$, Chemosphere, 183, 176185, https://doi.org/10.1016/j.chemosphere.2017.05.094, 2017.

Yuan, B., Shao, M., de Gouw, J., Parrish, D. D., Lu, S., Wang, M., Zeng, L., Zhang, Q., Song, Y., Zhang, J., and $\mathrm{Hu}$, M.: Volatile organic compounds (VOCs) in urban air: How chemistry affects the interpretation of positive matrix factorization (PMF) analysis, J. Geophys. Res.-Atmos., 117, https://doi.org/10.1029/2012jd018236, 2012.

Zhang, J. K., Sun, Y., Liu, Z. R., Ji, D. S., Hu, B., Liu, Q., and Wang, Y. S.: Characterization of submicron aerosols during a month of serious pollution in Beijing, 2013, Atmos. Chem. Phys., 14, 2887-2903, https://doi.org/10.5194/acp-14-2887-2014, 2014.

Zhang, Q., Jimenez, J. L., Canagaratna, M. R., Ulbrich, I. M., Ng, N. L., Worsnop, D. R., and Sun, Y.: Understanding atmospheric organic aerosols via factor analysis of aerosol mass spectrometry: a review, Anal. Bioanal. Chem., 401, 3045-3067, https://doi.org/10.1007/s00216-011-5355-y, 2011.

Zhang, Q., Zheng, Y., Tong, D., Shao, M., Wang, S., Zhang, Y., Xu, X., Wang, J., He, H., Liu, W., Ding, Y., Lei, Y., Li, J., Wang, Z., Zhang, X., Wang, Y., Cheng, J., Liu, Y., Shi, Q., Yan, L., Geng, G., Hong, C., Li, M., Liu, F., Zheng, B., Cao, J., Ding, A., Gao, J., Fu, Q., Huo, J., Liu, B., Liu, Z., Yang, F., He, K., and Hao, J.: Drivers of improved $\mathrm{PM}_{2.5}$ air quality in China from 2013 to 2017, P. Natl. Acad. Sci. USA, 116, 24463-24469, https://doi.org/10.1073/pnas.1907956116, 2019.

Zheng, B., Tong, D., Li, M., Liu, F., Hong, C., Geng, G., Li, H., Li, X., Peng, L., Qi, J., Yan, L., Zhang, Y., Zhao, H., Zheng, Y., He, K., and Zhang, Q.: Trends in China's anthropogenic emissions since 2010 as the consequence of clean air actions, Atmos. Chem. Phys., 18, 14095-14111, https://doi.org/10.5194/acp-18-140952018, 2018. 